\title{
Mathematical Modeling of Hybrid Renewable Energy System: A Review on Small Hydro-Solar-Wind Power Generation
}

\author{
Binayak Bhandari', Shiva Raj Poudel', Kyung-Tae Lee', and Sung-Hoon Ahn ${ }^{1,2,1}$ \\ 1 Department of Mechanical \& Aerospace Engineering, Seoul National University, Seoul, South Korea, 151-742 \\ 2 Department of Mechanical Engineering, University of Washington, Stevens Way, Box 352600, Seattle, WA, USA, 98195 \\ \# Corresponding Author / E-mail: ahnsh@snu.ac.kr, TEL: +82-2-880-7110, FAX: +82-2-888-9073
}

\begin{abstract}
Harnessing energy from alternative energy source has been recorded since early history. Renewable energy is abundantly found anywhere, free of cost and has non-polluting characteristics. However, these energy sources are based on the weather condition and possess inherited intermittent nature, which hinders stable power supply. Combining multiple renewable energy resources can be a possible solution to overcome defects, which not only provides reliable power but also leads to reduction in required storage capacity. Although an oversized hybrid system satisfies the load demand, it can be unnecessarily expensive. An undersized hybrid system is economical, but may not be able to meet the load demand. The optimal sizing of the renewable energy power system depends on the mathematical model of system components. This paper summarizes the mathematical modeling of various renewable energy system particularly PV, wind, hydro and storage devices. Because of the nonlinear power characteristics, wind and PV system require special techniques to extract maximum power. Hybrid system has complex control system due to integration of two (or more) different power sources. The complexity of system increases with maximum power point tracking (MPPT) techniques employed in their subsystems. This paper also summarizes mathematical modeling of various MPPT techniques for hybrid renewable energy systems.
\end{abstract}

\section{Introduction}

At present fossil fuels contribute as the world's major energy sources. The non-renewable nature of fossil fuel and increasing energy demand have made it scarcer than before and therefore its price is skyrocketing. On the other hand renewable energy such as wind and solar is omnipresent free and abundant in nature. Since the renewable energy technologies are improving, the electricity cost produced by renewable form is certainly going to decrease significantly in near future ${ }^{1-3}$ Energy crisis, ever increasing oil prices, climate changes due to greenhouse gases and limitations imposed by Kyoto protocol in production of these gases have increased people's attention towards effective, efficient, ${ }^{4}$ sustainable and almost pollution free renewable energy systems. ${ }^{5}$

Even though renewable energy is novel, it is stochastic in nature. Its availability is sporadic and should be complemented by other power sources like batteries in most of cases. ${ }^{6-8}$ Due to intermittent nature of the renewable energy resources, system using single renewable energy source leads to oversized components and unnecessary operational and lifecycle cost. ${ }^{9}$ Two or more forms of energy resources can be combined to form a hybrid energy system that complements the drawbacks in each individual energy resources. Therefore, the design goals for hybrid power system are the minimization of power production cost, minimization of power purchase from grid (if it is connected to grid), reduction in emission, reduction of the total life cycle cost and increase in reliability of the power generation of system. ${ }^{2,10,11}$

Integrated system of two or more renewable energy systems, also known as hybrid renewable energy system (HRES), is gaining popularity because the sources can complement each other to provide higher quality and more reliable power to customer than single source system. ${ }^{12,13}$ A HRES can be standalone or grid connected. Standalone systems need to have generation and storage capacity large enough to handle the load. In a grid connected system, the size of storage device can be relatively smaller because deficient power can be obtained from the grid. A grid connected HRES can supply electricity to both load 
and the grid. However, when connected to grid, proper power electronic controllers are required to control voltage, frequency, harmonic regulations, and load sharing. Based on the type of HRES, the operating mode of HRES can be classified into island mode where the generated electricity is consumed locally and grid connected mode where the renewable energy source is connected to the grid. ${ }^{12-14}$

\section{Literature Survey}

Diaf et al. ${ }^{15}$ proposed a hybrid PV-Wind system in which the AC power form the wind is directly supplied to the load via un-interruptible power supply (UPS). The excess power, if available, is used to charge the battery through an AC/DC converter. The power obtained from the $\mathrm{PV}$ is also used in charging the battery via a DC/DC converter. In case of peak load, power is supplied from battery to the load through a DC/ AC converter. Jeon et al. ${ }^{16}$ studied the characteristics of solar cell through various extreme environmental conditions.

Hashimito et al. ${ }^{17}$ discussed stand-alone wind-PV hybrid system with a secondary backup battery that ensures uninterruptable supply of electricity to a radio base station in an island. Their system consists of cylindrical PV modules mounted on wind generator pole to save installation space and cost. Relationship between system idle time and backup battery capacity was studied and battery bank was designed to bring the system idle time to zero.

Sharaf and El-sayed ${ }^{18}$ discussed application of wind-PV hybrid system in a micro grid. Their system is consisted of a common DC and common AC collection bus interface. The system employs permanent magnet DC generator to convert the wind kinetic energy into DC power. The power obtained from $\mathrm{PV}$, which is also $\mathrm{DC}$, is connected to common DC bus.

Bakos $^{19}$ performed the feasibility study of wind-pumped hydro storage system assisted by diesel generator in case of power shortage. The system is designed as a wind farm which supplies to the load first. Excess energy if available is used for pumping water from lower tank to the higher reservoir so that the excess energy is stored as hydro potential energy. When wind farm is incapable of covering the whole load, the hydro system is called into operation and energy is supplied from both wind and hydro. If further energy deficiency exists, then deficit power is supplied by the diesel generator. The water reservoir acts as an energy storage so it is designed based on energy autonomy days. Monte Carlo analysis considering the linear characteristic of wind energy system and undamaged hydro system has been performed to verify the feasibility.

Bekele and Tedesse ${ }^{20}$ suggested a PV-hydro-wind hybrid system which can supply uninterrupted electricity for a village in Ethiopia. HOMER was used to optimize six small hydropower potentials together with wind PV systems. Due to the limitations of HOMER to handle more than one hydro resource at a time, optimization was performed by taking a nominal hydropower with total sum capacity of all small sites. Besides the primary purpose of lighting, they have considered electricity for cooking and running flour mills along with TVs and radio in their load calculation.

Ram Prabhakar and Ragavan ${ }^{14}$ discussed power management strategies in battery assisted PV-wind-hydro hybrid system. A control technique was developed, which estimates the load through energy balance model, DC-link voltage control and drop control. The system is capable of multi-mode operation i.e. wind-hydro-solar, wind-solar, hydrosolar, and wind-hydro owing to non-availability of any renewable energy resource. When weather is favorable, PV and wind are surplus. Then water is stored in reservoir for future use. The sequence of operation used in case of power scarcity is solar, wind, battery and hydro.

Saheb-Koussa et al. ${ }^{21}$ presented results of techno-economic analysis of PV/wind/diesel hybrid system. For all the six sites they studied, they found out that stand alone PV is a better solution considering the economic aspects. But there would be deficit during the winter season, and using a hybrid system overcome this effect. Their study suggested that hybrid system would be reliable but is not economic.

Fadaeenejad et al. ${ }^{22}$ studied PV-wind-battery hybrid and PV-winddiesel-battery hybrid with aim of rural electrification in Malaysia. For optimization of HRES iHOGA software developed by Dr. Rodolfo, Dufo-Lopez has been used. This study suggested PV-wind-battery hybrid as a better option. In a similar analysis, Goodbody et al. ${ }^{23}$ performed the study on integration of renewable energy systems in Ireland. System optimization was carried using HOMER, diurnal and seasonal variation of load was taken into consideration for optimization. This study has also considered space heating in the application of HRES and cost of fuel to do so, but the capital, maintenance or replacement cost is not taken into account due to limitations of HOMER. Ireland has high wind potential so wind energy was found to feature in most of stand-alone or grid connected hybrid systems. Biogas harvesting with large bio-digester was suggested to be cost-efficient for large community. Even though some regions simulated contains hydropower in the optimal design, the installation was found to be difficult in those regions because of the geographical constraints.

Akikur et al. ${ }^{24}$ carried a study on standalone solar and hybrid systems. Solar-wind hybrid, solar-hydro hybrid, solar-wind-diesel hybrid and solar-wind-diesel-hydro/biogas hybrid have been discussed, and viability and significance of solar energy (both in standalone and hybrid form) in global electrification have been shown in this study.

Djamel and Abdallah ${ }^{25}$ discussed power quality control of grid connected wind-solar hybrid system that employs a battery connected in the common DC bus. Though the system is said to be grid connected much has not been discussed. A fixed speed wind turbine has been employed so power control on high wind speed has been done by stall control. Power control in PV has been done by employing MPPT tracking that uses perturb and observe (P\&O) method.

Meshram et al. ${ }^{26}$ proposed a hypothetical grid connected solar-hydro hybrid system. As solar energy is abundant in summer, grid connected solar system supplies the power while hydro system is cutoff during operation. Similarly during rainy season when water is abundant, grid connected hydro system is brought in operation and solar system is cut off. During other season the system operates in hybrid mode. The proposed system has $10 \mathrm{~kW}$ solar capacity and $7.5 \mathrm{~kW}$ hydro capacity. $11 \mathrm{kV} \mathrm{AC}$ line is used to transmit the electricity form production site; it is then connected to $132 \mathrm{kV}, 2500$ MNA grid line through step down transformer, before supplying to customer supply; it is stepped down to $415 \mathrm{~V}$ for household usage.

Ismail et al. ${ }^{27}$ performed a feasibility study and techno-economic analysis of a PV system with batteries and micro turbine- micro turbine 
acting as backup supply in the system. Component sizing and optimization have been performed by iterative method to minimize cost of energy (COE) production. Comparison of standalone PV, micro turbine and hybrid system is also performed in this study. The study found that $\mathrm{COE}$ of standalone micro turbine was cheaper with very small difference. Sensitivity analysis of the system has also been performed by considering project life time, cost of natural gas, PV panels, battery bank, bidirectional inverter and charge regulator. The sensitivity analysis result showed hybrid system as the better alternative. In similar study Daud and Ismail ${ }^{28}$ designed and analyzed a PV-wind-diesel hybrid system for a family house in Palestine considering efficiency, reliability along with the dumped electric power. A software that is capable of changing the variable of hybrid energy system was developed to perform the analysis. High quantity of dump energy was found during the simulation because the system is designed for the worst case. In order to utilize the dump energy power supply to street light, water pumping has been suggested. Economic analysis of this system in terms of COE hybrid system lags behind purchasing grid electricity. The study concludes that if remote location, subsidy levels, cost of renewable energy equipment and environmental effects are taken into account then hybrid systems justify their use. In another study, the same authors ${ }^{29}$ analyzed PV-battery-diesel hybrid system which concluded the hybrid system as best alternative when the diesel generator is used as backup source. Kalantar and Mousavi ${ }^{5}$ also performed similar kind of study and proposed wind-solar-micro turbine-battery hybrid system. In their system the micro-turbine and battery act as a backup power supply during energy deficiency.

Menshsari et al. ${ }^{30}$ discussed the optimization of hydro-wind-solar-fuel cell hybrid using ant colony algorithm. PV, wind and electrolyzer are connected through a common DC bus which in turn is connected to AC bus via $\mathrm{DC} / \mathrm{AC}$ transducer. The hydroelectric generator is also connected to the AC bus which is then used to supply to the load. System reliability was also evaluated using loss of power supply probability (LPSP). This system has been optimized for cost and reliability.

On different application of hybrid systems, Vitali and Ricci ${ }^{31}$ installed the solar wind hybrid system for street lighting system that employs 3 Savonius rotors along with PV panels placed at the top of the lamp post. Two different types of rotors; a 2 stage ( 90 degree staggered) straight rotor and helical rotor with $105^{\circ}$ maximum section rotation were tested. Helical rotor was found to have better performance with coefficient of performance, $C_{p}$ values reaching maximum of 0.21 . A hybrid controller that can cut-out during high speed and low speed conditions, disconnect load at low battery condition and switch off renewable energy source when the battery is fully charged is also employed in this system.

Saha et al. ${ }^{32}$ proposed a hypothetical hybrid system that employed wind-solar-biogas-micro hydro hybrid as major energy sources and also used diesel generator as emergency backup source. Micro hydro was modeled to supply constant base load while peak power was supplied by solar, wind biomass, and diesel generator. Biogas gives freedom to control the output power thus it helps in balancing the energy deficit from solar-wind and reduces output fluctuation. The optimum combination of weather dependent non-conventional energy sources- solar and wind, and weather independent energy source like biomass and hydro will completely eliminate the weather dependency of the renewable energy source and also ensures least cost of production. The power production cost form hydro is the least so designing it to supply for the base load significantly decreases the cost of production of electricity. The sequence of operation of these power sources in case of power deficiency is: hydro, wind, PV, battery, biogas and diesel engine. Hour by hour analysis of the proposed system has been simulated in MATLAB though the analysis does not consider the synchronization of the different power system.

Suha Yazici et al..$^{33}$ proposed PV/wind/fuel cell hybrid power system for powering amenities in a recreational vehicle (RV) with studio type living facilities called as $\mathrm{H}_{2}$ EkoKaravan. Wind and solar are the primary energy sources of the system which supplies to load and charge batteries. Excess energy, if available, would be used for electrolysis of water which can be used to power the fuel cell or can be burnt as fuel in hydrogen cooker. In case of power deficiency following hierarchy is used for power supply: solar, wind, battery and fuel cell. The system has been designed for three days of autonomy. Vertical axis control and MPP tracking has also been employed in the solar panel. PV panel positions automatically according to GPS date and time data. Component sizing is done by using a software called HOGA which considers daily load profile, solar and wind data, equipment options, price, and control strategy. The usability of this vehicle has been displayed as a mobile medical center for remote areas, as an emergency response vehicle, relief co-ordination hub or communication center when grid power is unavailable.

Bhandari et al. ${ }^{34}$ proposed two tri-hybridization processes and implemented one of the process for rural electrification. The tri-hybrid system includes hydro-wind and PV systems.

\section{Mathematical Modeling}

A hybrid energy system might consist of various renewable energy conversion component like wind turbine, PV array and hydro turbines as well as conventional non-renewable generators like diesel generators, micro turbine and storage device like battery. A hybrid energy system might have all or part of it. In order to correctly select the components and subsystems for optimal sizing of the entire system, the first step is the modeling of individual components. Modeling process enables to identify and assists in knowing the components' characteristics and supports in decision making. The details of modeling is reflected by its correct prediction of performance, however it is too complex or extremely time consuming to design a perfect model. A sufficiently appropriate model should be tradeoff between complexity and accuracy. Performance of individual component is either modeled by deterministic or probabilistic approaches. ${ }^{35}$ General methodology for modeling energy system is described below:

\subsection{PV System}

\subsubsection{PV Potential Assessment}

Power output of a PV array is based on solar irradiance and ambient temperature. The power output in this model is calculated as ${ }^{15}$

$$
P_{p v}=\eta_{p v g} A_{p v g} G_{t}
$$

where $\eta_{p v g}$ is PV generation efficiency, $A_{p v g}$ is PV generator area $\left(\mathrm{m}^{2}\right)$, and $G_{t}$ is solar irradiation in tilted module plane $\left(\mathrm{W} / \mathrm{m}^{2}\right) . \eta_{p v g}$ is further 
defined as

$$
\eta_{p v g}=\eta_{r} \eta_{p c}\left[1-\beta\left(T_{c}-T_{c \text { ref }}\right)\right]
$$

where $\eta_{p c}$ is power conditioning efficiency which is equal to one when MPPT is used, and $\beta$ is temperature coefficient $\left((0.004-0.006)\right.$ per $\left.{ }^{0} C\right)$, and $\eta_{r}$ is the reference module efficiency, and $T_{\text {cref }}$ is reference cell temperature in ${ }^{\circ} \mathrm{C}$. Reference temperature $\left(T_{\text {cref }}\right)$ can be obtained by relation

$$
T_{c}=T_{a}+\left(\frac{N O C T-20}{800}\right) G_{t}
$$

where $T_{a}$ is ambient temperature in ${ }^{0} \mathrm{C}, N O C T$ is nominal operating cell temperature in ${ }^{\circ} C$, and $G_{t}$ is solar irradiation in tilted module plane $\left(\mathrm{W} / \mathrm{m}^{2}\right)$.

The total radiation in the solar cell considering normal and diffuse solar radiation can be estimated as ${ }^{36}$

$$
I_{T}=I_{b} R_{b}+I_{d} R_{d}+\left(I_{b}+I_{d}\right) R_{r}
$$

\subsubsection{System Modeling}

Solar cell, the building block of the solar array, is basically a P-N junction semiconductor capable of producing electricity due to photovoltaic effect. ${ }^{37} \mathrm{PV}$ cells are interconnected in series-parallel configuration to form a PV array. ${ }^{38}$ Using ideal single diode as shown in Fig. 1, for an array with $N_{s}$ series connected cells and $N_{p}$ parallelconnected cells, the array current may be related to the array voltage as

$$
I=N_{p}\left[I_{p h}-I_{r s}\left[\exp \left(\frac{q\left(V+I R_{s}\right)}{A K T N_{s}}-1\right)\right]\right]
$$

where

$$
I_{r s}=I_{r r}\left(\frac{T}{T_{r}}\right)^{3} \exp \left[\frac{E_{G}}{A K}\left(\frac{1}{T_{r}}-\frac{1}{T}\right)\right]
$$

and $q$ is the electron charge $\left(1.6 \times 10^{-9} \mathrm{C}\right), K$ is Boltzmann's constant, $A$ is the diode ideality factor, $T$ is the cell temperature $(\mathrm{K}) . I_{r s}$ is the cell reverse saturation current at $T, T_{r}$ is the cell referred temperature, $I_{r r}$ is the reverse saturation current at $T_{r}, E_{G}$ is the band gap energy of the semiconductor used in the cell. The photo current $I_{p h}$ varies with the cell's temperature and radiation as follows

$$
I_{p h}=\left[I_{S C R}+k_{i}\left(T-T_{r}\right) \frac{S}{100}\right]
$$

where $I_{S C R}$ is cell short circuit current at reference temperature and radiation, $k_{i}$ is the short circuit current temperature coefficient and $S$ is the solar radiation in $\left(\mathrm{mW} / \mathrm{cm}^{2}\right)$.

Solar cells are generally modeled as single diode in Fig. 2 and double diode circuit model in Fig. 3.

Single diode model uses an additional shunt resistance in parallel to ideal shunt diode model. $I-V$ characteristics of PV cell can be derived using single diode model, as follows: ${ }^{39}$

$$
\begin{gathered}
I=I_{p h}-I_{D} \\
I=I_{p h}-I_{0}\left[\exp \left(\frac{q\left(V+R_{s} I\right)}{A K T}-1\right)-\frac{V+R_{s} I}{R_{s h}}\right]
\end{gathered}
$$

where $I_{p h}$ is photo current (A), $I_{D}$ is the diode current (A), $I_{0}$ is the

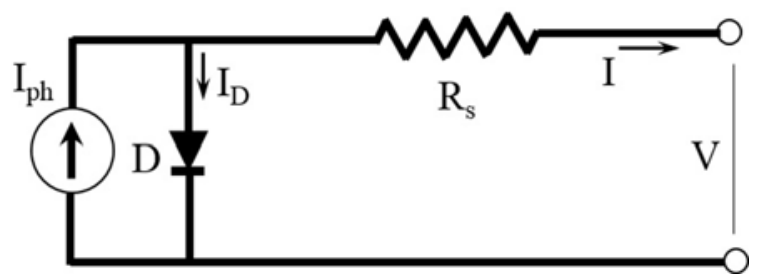

Fig. 1 Ideal single diode PV cell model

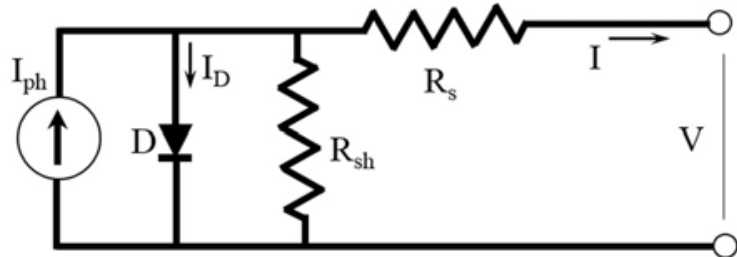

Fig. 2 Single diode PV cell model

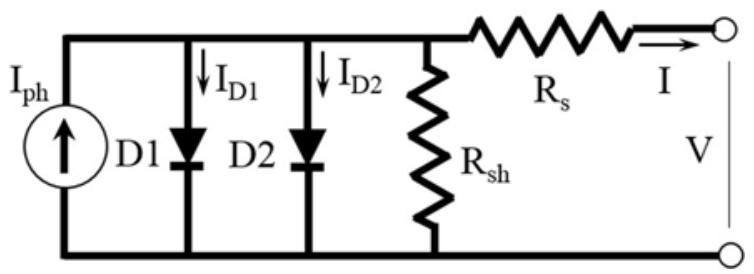

Fig. 3 Double diode PV model

inverse saturation current (A), $A$ is the diode constant, $q$ is the charge of the electron $\left(1.6 \times 10^{-9} \mathrm{C}\right), K$ is Boltzmann's constant, $T$ is the cell temperature $\left({ }^{0} \mathrm{C}\right), R_{s}$ is the series resistance $(\mathrm{ohm}), R_{s h}$ is shunt resistance (Ohm), $I$ is the cell current (A), and $V$ is cell voltage (V).

Output current of the PV cell using two diode model can be described as ${ }^{40}$

$$
I=I_{P V}-I_{D 1}-I_{D 2}-\left(\frac{V+I R_{S}}{R_{S H}}\right)
$$

where

$$
\begin{aligned}
& I_{D 1}=I_{01}\left[\exp \left(\frac{V+I R_{S}}{a_{1} V_{T 1}}\right)-1\right] \\
& I_{D 2}=I_{02}\left[\exp \left(\frac{V+I R_{S}}{a_{2} V_{T 2}}\right)-1\right]
\end{aligned}
$$

$I_{01}$ and $I_{02}$ are reverse saturation current of diode 1 and diode 2, $V_{T 1}$ and $V_{T 2}$ are thermal voltage of respective diode. $a_{1}$ and $a_{2}$ represent the diode ideality constants.

Simplified model for PV system modeling proposed by Zhou et al. ${ }^{41}$ is presented below

$$
\begin{gathered}
v_{o c}=\frac{V_{o c}}{c K T / q} \\
P_{\max }=\frac{\frac{V_{o c}}{c K T / q}-\ln \left(\frac{V_{o c}}{c K T / q}+0.72\right)}{\left(1+\frac{V_{o c}}{n K T / q}\right)}\left(1-\frac{R_{s}}{V_{o c} / I_{s c}}\right)\left(\frac{V_{o c 0}}{1+\beta \ln \frac{G_{0}}{G}}\right)\left(\frac{T_{0}}{T}\right)^{\gamma} I_{s c 0}\left(\frac{G}{G_{o}}\right)^{\alpha}
\end{gathered}
$$

where $v_{o c}$ is normalized value of the open-circuit voltage $V_{o c}$ with respect to the thermal voltage $V_{t}=n k T / q, n$ is the ideality factor $(1<$ $n<2$ ), $K$ is the Boltzmann constant, $T$ is the PV module temperature in kelvin, $q$ is the electron charge, $\alpha$ is the factor responsible for all the non-linear effects that the photocurrent depends on, $\beta$ is a PV module 
technology specific-related dimensionless coefficient, and $\gamma$ is the factor considering all the non-linear temperature-voltage effects.

Equation (14) represents the maximum power output of a single PV module. A real system consists of the number of PV modules connected in series and parallel. The total power output for an array with $N_{s}$ series connected cells and $N_{p}$ parallel-connected cells with $P_{M}$ power of each module will be

$$
P_{\text {array }}=N_{s} N_{p} P_{M}
$$

\subsection{Wind Power System}

\subsubsection{Wind Potential Assessment}

The fundamental equation governing the mechanical power of the wind turbine is given by

$$
P_{w}=\frac{1}{2} C_{p}(\lambda, \beta) \rho A V^{3}
$$

where $\rho$ is air density $\left(\mathrm{kg} / \mathrm{m}^{3}\right), C_{p}$ is power coefficient, $A$ is intercepting area of the rotor blades $\left(\mathrm{m}^{2}\right), V$ is average wind speed $(\mathrm{m} / \mathrm{s}), \lambda$ is tip speed ratio. The theoretical maximum value of the power coefficient $C_{p}$ is 0.593 , also known as Betz's coefficient. ${ }^{42}$

The Tip Speed Ratio (TSR) for wind turbine is defined as the ratio of rotational speed of the tip of a blade to the wind velocity. Mathematically,

$$
\lambda=\frac{R \omega}{V}
$$

where $R$ is radius of turbine $(\mathrm{m}), \omega$ is angular speed $(\mathrm{rad} / \mathrm{s}), V$ is average wind speed $(\mathrm{m} / \mathrm{s})$.

The energy generated by wind can be obtained by

$$
Q_{w}=P \times(\text { Time })[\mathrm{kWh}]
$$

Sometimes because of various factors the velocity of wind at any particular height cannot be obtained by direct measurement. In that case the data at any reference height can be interpolated or extrapolated to find the wind speed at any particular height. The wind velocity is measured at a lower height can be error prone due to vegetation, shading and obstacles in the vicinity. ${ }^{20}$

$$
v(z) \ln \left(\frac{z_{r}}{z_{o}}\right)=v\left(z_{r}\right) \ln \left(\frac{z}{z_{0}}\right)
$$

where $Z_{r}$ is reference height (m), $Z$ is the height where wind speed is to be determined, $Z_{0}$ is the measure of surface roughness $(0.1-0.25$ for crop land), $v(z)$ is wind speed at height $\mathrm{z}(\mathrm{m} / \mathrm{s})$, and $v\left(z_{r}\right)$ is wind speed at reference height $z(\mathrm{~m} / \mathrm{s})$.

Cut-in speed is a very low wind speed at which the turbine first starts to rotate and generate power. Cut-out speed is the high wind speed at which the forces on the turbine structure is high as a result there is a risk of the damage to the rotor. To prevent damage, braking system is employed to bring the rotor to stand-still. Rated output speed is the wind speed between cut-in speed and cut-out speed where the power output reaches the maximum limit that the electrical generator is capable of and is called rated power output. The power output in terms of wind speed can be estimated using ${ }^{43}$

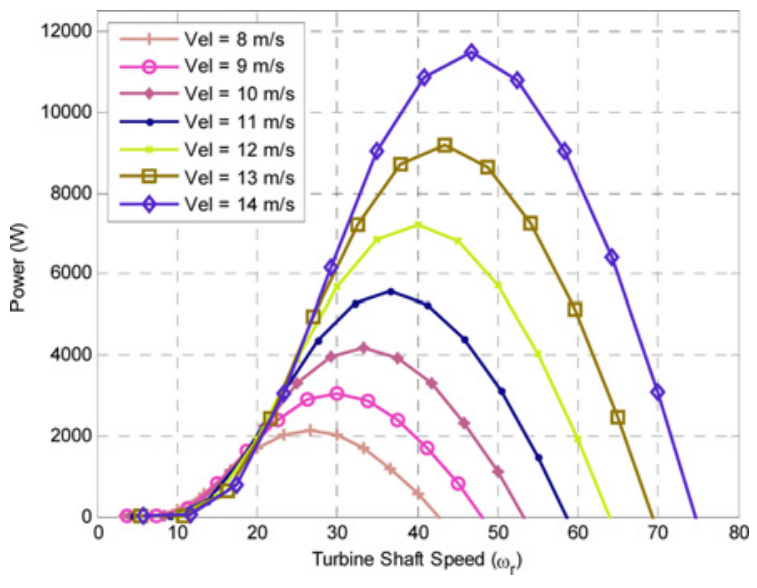

Fig. 4 Wind Turbine power curve

$$
P_{w}(v)=\left\{\begin{array}{lr}
\frac{v^{k}-v_{C}^{k}}{v_{R}{ }^{k}-v_{C}^{k}} \cdot P_{R} & v_{C} \leq v \leq v_{R} \\
P_{R} & v_{R} \leq v \leq v_{F} \\
0 & v \leq v_{C} \text { and } v \geq v_{F}
\end{array}\right.
$$

where $P_{R}$ is rated power, $v_{C}$ is cut-in wind speed, $v_{R}$ is rated wind speed, $v_{F}$ is rated cut-out speed, and $k$ is the Weibull shape factor. Kalantar and Mousavi ${ }^{5}$ used value of $k$ as 1 while Daif et al. ${ }^{15}$ and Yang et al. ${ }^{44}$ used the value of $k$ as 2, Chedid et al. ${ }^{45}$ took the value as 3 .

For the fixed size of rotor blade, and the power generation changes with change in wind velocity as shown in Fig. 4. So, with the change in wind velocity the optimum generator speed corresponding to max power should be determined for the changed velocity. The angular speed of generator must be changed in order to extract the maximum power, and this process is known as maximum power point tracking (MPPT). The next section is dedicated for MPPT. When the blade pitch angle is zero, the power coefficient is maximized for an optimum TSR. ${ }^{5}$

The optimum rotor speed is given by:

$$
\omega_{o p t}=\frac{\lambda_{o p t}}{R} V_{w n}
$$

which gives

$$
V_{w n}=\frac{R \omega_{o p t}}{\lambda_{o p t}}
$$

where $\omega_{\text {opt }}$ is optimum rotor angular speed in $\mathrm{rad} / \mathrm{s}, \lambda_{\text {opt }}$ is optimum tip speed ratio, $R$ is radius of turbine in meters and $V_{w n}$ is wind speed in $\mathrm{m} / \mathrm{s}$

\subsubsection{Drive Train Modeling}

Drive train transfers high aerodynamic torque at rotor to low speed shaft of generator through gearbox. Some generators are directly coupled with the rotor to reduce complexity so they do not need modeling of this part.

Drive train can be modeled using one mass model and two mass model. Details of which can be found elsewhere. ${ }^{46,47}$ Shi et al. ${ }^{48}$ developed mathematical model based on the torsional multibody dynamic model. 


$$
\left[\begin{array}{c}
\dot{\omega}_{t} \\
\dot{\omega}_{g} \\
\dot{T}_{l s}
\end{array}\right]=\left[\begin{array}{ccc}
-\frac{K_{t}}{J_{t}} & 0 & -\frac{1}{J_{t}} \\
0 & -\frac{K_{g}}{J_{g}} & \frac{1}{n_{g} J_{g}} \\
\left(B_{l s}-\frac{K_{l s} K_{r}}{J_{r}}\right) & \frac{1}{n_{g}}\left(\frac{K_{l s} K_{r}}{J_{g}}-B_{l s}\right) & -K_{l s}\left(\frac{J_{r}+n_{g}^{2} J_{g}}{n_{g}^{2} J_{g} J_{r}}\right.
\end{array}\right]\left[\begin{array}{c}
\omega_{t} \\
\omega_{g} \\
T_{l s}
\end{array}\right]+\left[\begin{array}{c}
\frac{1}{J_{r}} \\
0 \\
\frac{K_{l s}}{J_{r}}
\end{array}\right] T_{m}+\left[\begin{array}{c}
0 \\
-\frac{1}{J_{g}} \\
\frac{K_{l s}}{n_{g} J_{g}}
\end{array}\right] T_{g}
$$

\section{One Mass Model}

If a perfectly rigid low-speed shaft is assumed, a single mass model (as shown in Fig. 5) of the turbine can be considered

$$
J_{t} \dot{\omega}_{t}=T_{a}-K_{t} \omega_{t}-T_{g}
$$

and

$$
\begin{gathered}
J_{t}=J_{r}+n_{g}^{2} J_{g} \\
K_{t}=K_{r}+n_{g}^{2} K_{g} \\
T_{g}=n_{g} T_{e m}
\end{gathered}
$$

where $J_{t}$ is the turbine rotor moment of inertia in $\left[\mathrm{kg} \mathrm{m}^{2}\right], \omega_{t}$ is low shaft angular speed in $\left[\mathrm{rad} \mathrm{sec}^{-2}\right], K_{t}$ is the turbine damping coefficient in $[\mathrm{Nm}$ $\left.\mathrm{rad}^{-1} \mathrm{sec}^{-1}\right]$ representing aerodynamic resistance, and $K_{g}$ is generator damping coefficient in $\left[\mathrm{Nm} \mathrm{rad}^{-1} \mathrm{sec}^{-1}\right]$ representing mechanical friction and windage.

\section{Two Mass Model}

The schematic of two mass wind turbine system is shown in Fig. 6 . Bati and Brennam ${ }^{49}$ presented modeling of wind turbine of which the rotor side inertia $J_{r}$ is given by

$$
J_{t} \frac{d \omega_{t}}{d t}=T_{m}-T_{l s}-K_{t} \omega_{t}
$$

The low speed shaft torque is given by

$$
T=B_{l s}\left(\theta_{t}-\theta_{l s}\right)+K_{l s}\left(\omega_{t}-\omega_{l s}\right)
$$

The generator inertia $J_{g}$ is driven by the high speed shaft and braked by the electromagnetic torque $T_{g}$ of the generator

$$
J_{g} \frac{d \omega_{g}}{d t}=T_{h s}-K_{g} \omega_{g}-T_{g}
$$

If we assume the ideal gearbox with ratio $n$, then

$$
n=\frac{T_{l s}}{T_{h s}}=\frac{\omega_{g}}{\omega_{t}}=\frac{\theta_{g}}{\theta_{l s}}
$$

where the notations of which are the same as those of one mass model. $K_{l s}$ is the low-speed shaft damping coefficient in [ $\left.\mathrm{N} \mathrm{m} \mathrm{rad}^{-1} \mathrm{sec}^{-1}\right], \omega_{g}$ is high-speed shaft angular speed in $\left[\mathrm{rad} \mathrm{sec}^{-2}\right], T_{m}$ is turbine torque in [N m], $T_{l s}$ is low-speed shaft torque in $[\mathrm{N} \mathrm{m}], J_{g}$ is the generator rotor moment of inertia in $\left[\mathrm{kg} \mathrm{m}^{2}\right]$ and $T_{h s}$ is high speed shaft torque in $[\mathrm{Nm}]$.

After eliminating $T_{l s}$ time derivative from (27) and using (26) and (28), following dynamical system is derived.

$$
\frac{d T_{l s}}{d t}=\left(B_{l s}-\frac{K_{l s} K_{t}}{J_{t}}\right) \omega_{t}+\frac{1}{n}\left(\frac{K_{l s} K_{t}}{J_{g}}-B_{l s}\right) \omega_{g}-K_{l s}\left(\frac{J_{t}+n^{2} J_{g}}{n^{2} J_{t} J_{g}}\right) T_{l s}+\frac{K_{l s}}{J_{t}} T_{\alpha}+\frac{K_{l s}}{n J_{g}} T_{g}
$$

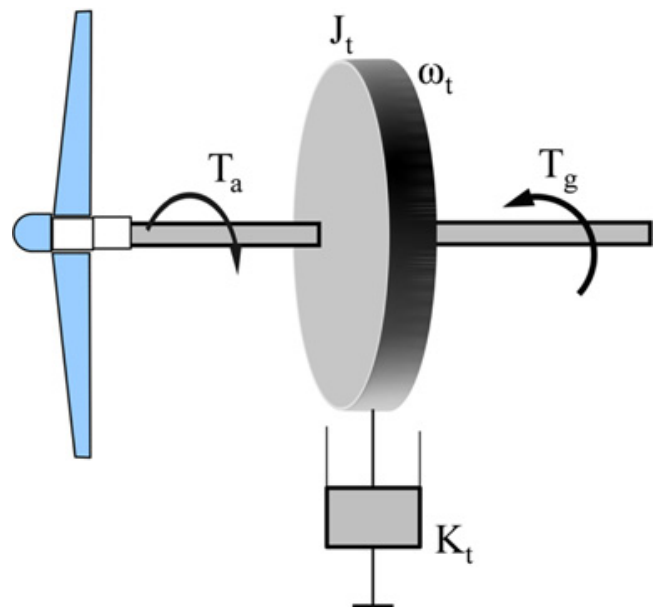

Fig. 5 One mass model of wind turbine system (Redrawn from ref. [47])

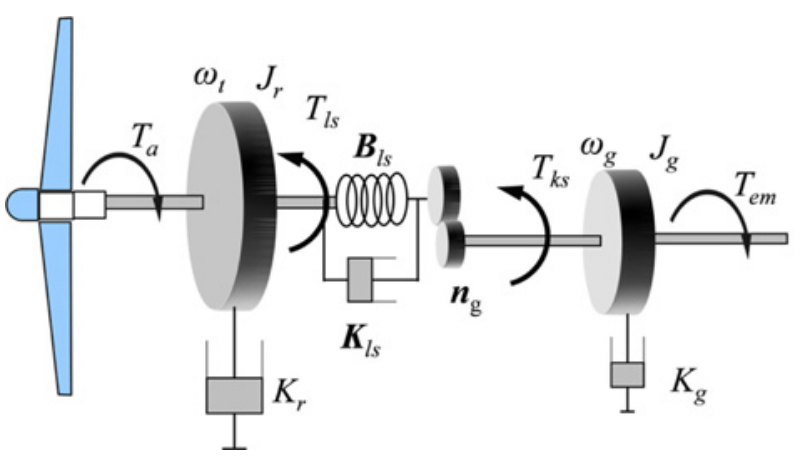

Fig. 6 Two mass model of wind turbine system (Redrawn from ref. [46])

where

$$
\begin{gathered}
K_{l s}=I G / L_{l \mathrm{~s}} \\
D_{l s}=\xi D_{\mathrm{s}}
\end{gathered}
$$

$$
\begin{aligned}
& \xi=\sqrt{1-\left(\frac{\omega}{\omega_{n}}\right)^{2}} \\
& D_{s}=2 \sqrt{K_{l s} m}
\end{aligned}
$$

and $\omega / \omega_{n}$ is ratio of shaft frequency of oscillation to the un-damped natural frequency of shaft, $m$ is mass of shaft, $I$ is second momentum of area about the axis of rotation, $L_{i s}$ is shaft length, $G$ is modulus of rigidity, $D_{s}$ is critical damping of shaft, and $\xi$ is damping ratio of shaft.

\subsubsection{Generator Modeling}

Both induction and synchronous generator can be used for wind turbine systems. Variable speed direct driven multi pole permanent magnet synchronous generator (PMSG) is also extensively used in wind power system because of it higher efficiency, low weight, less maintenance, easier controllability and no need for reactive and magnetizing current. ${ }^{3,50}$ The presence of gearbox in variable speed wind turbine generates extra burden of cost and maintenance. Using direct driven PMSG not only increases reliability but also decreases weight in nacelle. ${ }^{51-53}$

The model of PMSG is done based on d-q synchronous reference frame. PMSG voltage equation is given by

$$
V_{d}=-R_{s} i_{d}-L_{d} \frac{d i_{q}}{d t}+\omega L_{q} i_{q}
$$




$$
V_{q}=-R_{s} i_{q}-L_{q} \frac{d i_{q}}{d t}-\omega L_{d} i_{d}+\omega \lambda_{m}
$$

The electronic torque is given $b^{51}$

$$
T_{e}=1.5 \rho\left[\lambda i_{q}+\left(L_{d}-L_{q}\right) i_{d} i_{q}\right]
$$

where $L_{q}$ is q axis inductance, $L_{d}$ is $\mathrm{d}$ axis inductance, $i_{q}$ is q axis current, $i_{d}$ is d axis current, $V_{q}$ is q axis voltage, $V_{d}$ is d axis voltage, $\omega_{r}$ is angular velocity of rotor, $\lambda$ is amplitude of flux induced, and $p$ is number of pairs of poles.

In case of squirrel cage induction generator (SCIG) following equation in stationary $\mathrm{d}$-q frame of reference can be used for dynamic modeling ${ }^{5}$

$$
\left[\begin{array}{c}
V_{q s} \\
V_{d s} \\
V_{q r} \\
V_{d r}
\end{array}\right]=\left[\begin{array}{cccc}
R_{s}+p L s & 0 & p L_{m} & 0 \\
0 & R_{s}+p L_{s} & 0 & p L_{m} \\
p L_{m} & -\omega_{r} L_{m} & R_{r}+p L_{r} & -\omega_{r} L_{r} \\
\omega_{r} L_{m} & p L_{m} & \omega_{r} L_{r} & R_{r}+p L_{r}
\end{array}\right]\left[\begin{array}{c}
i_{q s} \\
i_{d s} \\
i_{q r} \\
i_{d r}
\end{array}\right]
$$

from stator side the equation are

$$
\begin{aligned}
\lambda_{d s} & =L_{s} i_{d s}+L_{m} i_{d r} \\
\lambda_{q s} & =L_{s} i_{q s}+L_{m} i_{d r} \\
L_{s} & =L_{i s}+L_{m} \\
L_{r} & =L_{l r}+L_{m} \\
V_{d s} & =R_{s} i_{d s}+\frac{d}{d t} \lambda_{d s} \\
V_{q s} & =R_{s} i_{q s}+\frac{d}{d t} \lambda_{q s}
\end{aligned}
$$

from rotor side the equation are

$$
\begin{gathered}
\lambda_{d r}=L_{r} i_{d r}+L_{m} i_{d s} \\
\lambda_{q r}=L_{r} i_{q r}+L_{m} i_{q s} \\
V_{d r}=R_{r} i_{d r}+\frac{d}{d t} \lambda_{d r}+\omega_{r} \lambda_{q r} \\
V_{q r}=R_{r} i_{q r}+\frac{d}{d t} \lambda_{q r}-\omega_{r} \lambda_{d r}
\end{gathered}
$$

For the air gap flux linkage the equations are

$$
\begin{aligned}
& \lambda_{d m}=L_{m}\left(i_{d s}+i_{d r}\right) \\
& \lambda_{q r}=L_{m}\left(i_{q r}+i_{q s}\right)
\end{aligned}
$$

where $R_{s}, R_{r}, L_{m}, L_{l s}, L_{l r}, \omega_{r}, i_{d}, i_{q}, V_{d}, V_{q}, \lambda_{d}$ and $\lambda_{q}$ are the stator winding resistance, motor winding resistance, magnetizing inductance, stator leakage inductance, rotor leakage inductance, electrical rotor angular speed, current, voltage, and fluxes respectively of the d-q model respectively.

The output power and torque of turbine $\left(T_{t}\right)$ in terms of rotational speed can be obtained by substituting (17) in (16)

$$
\begin{gathered}
P_{w}=\frac{1}{2} \rho A C_{p}(\lambda, \beta)\left(\frac{R \omega_{o p t}}{\lambda_{o p t}}\right)^{3} \\
T_{t}=\frac{1}{2} \rho A C_{p}(\lambda, \beta)\left(\frac{R}{\lambda_{\text {opt }}}\right)^{3} \omega_{o p t}
\end{gathered}
$$

The power coefficient $\left(C_{p}\right)$ is a nonlinear function expressed by the fitting equation ${ }^{51}$ in form

$$
C_{p}(\lambda, \beta)=c_{1}\left(c_{2} \frac{1}{\lambda_{i}}-c_{3} \beta-c_{4}\right) e^{-c_{5} \frac{1}{\lambda_{i}}}+c_{6} \lambda
$$

with,

$$
\frac{1}{\lambda_{i}}=\frac{1}{\lambda+0.08 \beta}-\frac{0.035}{\beta^{3}+1}
$$

The value of constants $c_{1}-c_{6}$ has been explained later section.

\subsection{Hydro Power System}

The first step in hydro modeling is to calculate the flow rate. The flow rate can be calculated if the catchment area of river is known in addition to the rainfall data (monthly, daily, and hourly). Catchment areas are the areas from which rain water flows into the river. The above procedure is for run off river type of hydro system. The hydro potential of a site is given by

$$
Q_{\text {site }}=K\left[\frac{A_{\text {site }}}{A_{\text {gauge }}}\right] Q_{\text {gauge }}
$$

where $A_{\text {site }}$ is catchment area of power plant $\left(\mathrm{m}^{2}\right), A_{\text {gauge }}$ is catchment area of gauge $\left(\mathrm{m}^{2}\right), Q_{\text {site }}$ is discharge at site $\left(\mathrm{m}^{3} / \mathrm{s}\right), Q_{\text {gauge }}$ is discharge at gauge $\left(\mathrm{m}^{3} / \mathrm{s}\right)$, and $K$ is scaling constant or function.

The mechanical power generated by the turbine is given by

$$
P=\eta_{\text {total }} \rho g Q H
$$

where $P$ is mechanical power output produced at the turbine, $\eta_{\text {total }}$ hydraulic efficiency of the turbine, $\rho$ is density of water $\left(1000 \mathrm{~kg} / \mathrm{m}^{3}\right)$, $g$ is acceleration due to gravity $\left(9.81 \mathrm{~m} / \mathrm{s}^{2}\right)$, and $\mathrm{H}$ is effective pressure head $(\mathrm{m})$.

\section{MPPT Tracking}

When it comes to power control, solar and wind show a special feature; unlike other power systems power generation cannot be controlled by controlling the fuel inflow rate or the amount of energy applied to the generator ${ }^{45,49}$ thus solar and wind demand for a special control system. The amount of energy that can be extracted from the wind does not only depend upon the wind speed but is mainly governed by tip speed ratio (TSR). ${ }^{54}$ In order to extract maximum energy from wind in a varying speed condition the rotational speed should be varied to maintain optimal value of TSR all the time.

In the similar way, the power generated by solar array depends upon insolation and temperature. The voltage-current relation and voltagepower relation are non-linear as shown in Fig. 7. Maximum power point (MPP) should be tracked for efficient extraction of solar energy in PV system during varying insolation conditions.

Maximum power from a wind-PV hybrid system can be extracted when maximum power point tracking (MPPT) is done on each of them. Since the variable for MPPT of wind and PV system is different, individual tracking system should be implemented for each system. Maximum power point tracking (MPPT) not only maximizes the system's efficiency but also minimizes the return period of the installation cost. $^{55}$ 

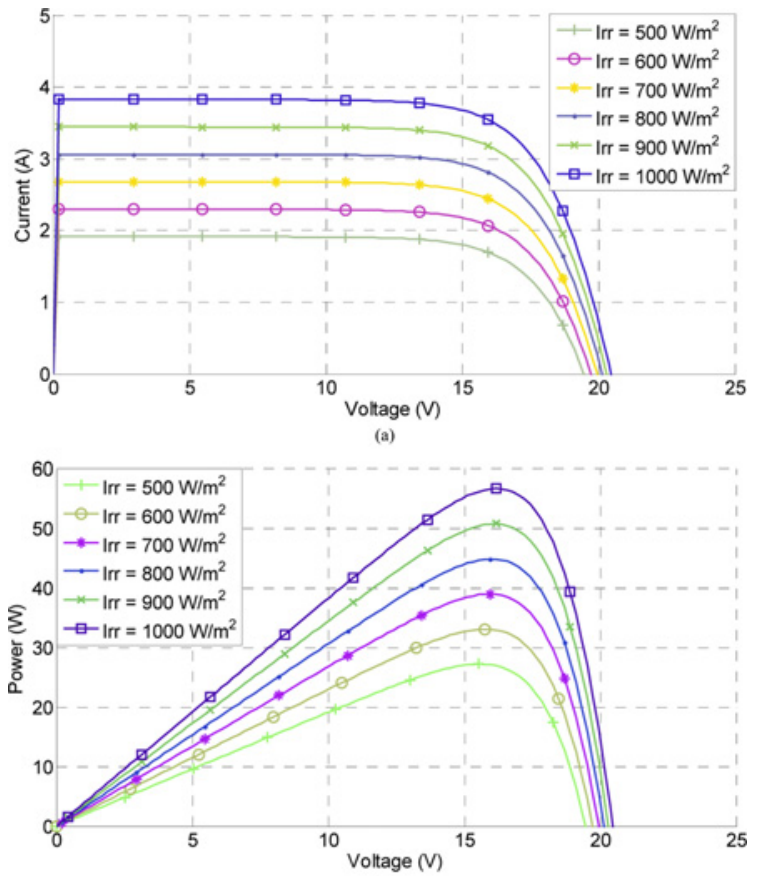

(b)

Fig. 7 Solar cell characteristics (a) voltage-current characteristics and (b) voltage-power characteristics

\subsection{MPPT Tracking in Wind}

Wind turbine can operate in two different modes: fixed speed and variable speed. Fixed speed turbine generator can be directly connected to grid or load while in a variable speed turbine power electronic device are used to convert variable frequency, variable power to constant frequency and power. The use of variable speed wind turbine has made possible to continuously adapt the rotational speed of the wind turbine relative to wind speed in a way the turbine operates at higher efficiency and decreases power fluctuations. ${ }^{7,56,57}$ Annual production increases by $5-10 \%$ in a variable speed turbine compared with in a fixed turbine. ${ }^{46}$

Fig. 8 shows relationship between coefficient of performance $\left(C_{p}\right)$ and tip speed ratio $(\lambda)$. From the figure it is clear that as the turbine speed changes there will be a corresponding maximum output power which is obtained when $C_{p}$ is maximized. The main objective of MPPT in wind is to search for the maximum $C_{p}$ condition in varying wind speed.

Maximum power point can be captured in a varying wind speed by keeping the tip ratio in its optimal value in a variable speed generation system. ${ }^{58}$ Maximum power output of the wind turbine is difficult to maintain at all wind speed conditions due to nonline ar characteristics of the wind turbine. ${ }^{6,59}$ So, there are various control strategies to track the maximum power of the wind turbine systems. Some techniques track maximum power by observing the change in power produced while some techniques need mechanical sensors that measure the wind speed to calculate the value of generator speed that forces it to operate in maximum power point thus they are sensitive to modeling uncertainties and become insensitive in some cases. ${ }^{56}$

\subsubsection{Perturb and Observe (P\&O) or Hill Climb Searching (HCS)}

The P\&O or HCS algorithm is an iterative method of obtaining MPP without previous knowledge of static characteristics. ${ }^{60}$ It

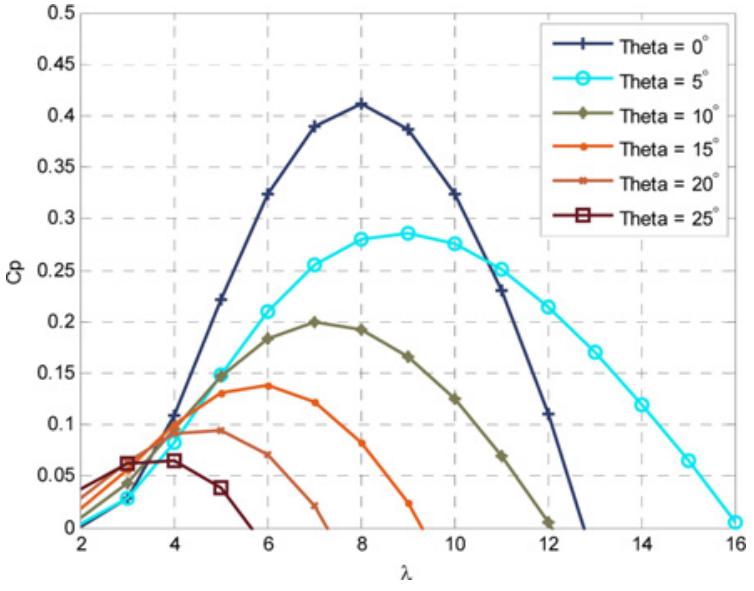

Fig. $8 \mathrm{CP}$ vs. $\lambda$ characteristics
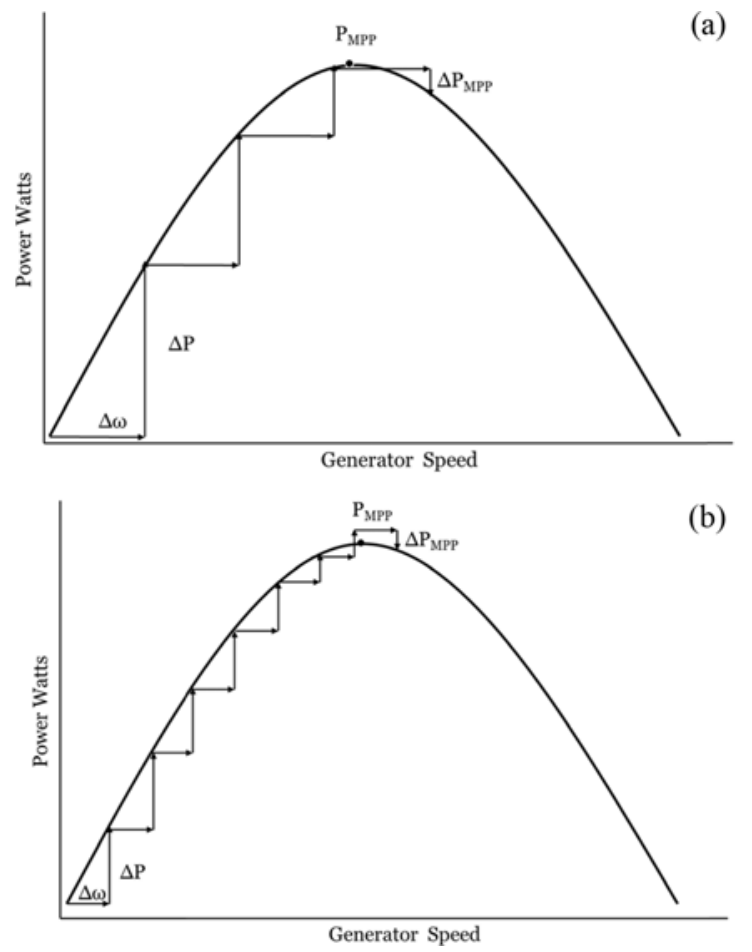

Fig. 9 Perturbation size in (a) is larger than (b) so computation speed in (a) is faster than (b) but it also oscillates more (redrawn from ref. [55])

continuously searches for maximum power operating point under fluctuating conditions. In this method rotor speed is changed by small step and the corresponding power output is observed. The next change of the rotor speed depends on the reading of the preceding power output. If increase in the output power is observed while increasing the rotor speed then the direction of perturbation signal is not altered. If decrease in the output power is observed while increasing the rotor speed then the direction of the perturbation signal is altered. ${ }^{6}$

HCS or P\&O algorithm does not require any prior knowledge of the system or any additional sensor, so it is the simplest MPPT algorithm. HCS control works well when turbine inertia is very small so that the turbine speed reacts to wind speed almost instantaneously. For large inertia wind turbines, the system output power is interlaced with the turbine mechanical power and rate of change of mechanically stored energy, which often renders the HCS method ineffective. ${ }^{61}$ Furthermore 
this method does not work well on fast varying systems like wind where the change is observed in seconds but is quite feasible in case of solar where the sun's irradiance changes over several minutes. Another major problem associated with this method is the selection of the optimum perturbation size. Larger perturbation step size increases the convergence but deteriorates the efficiency of MPPT due to oscillation around the MPP. Smaller size boosts MPPT efficiency, as shown in Fig. 7 but is slow and may be incapable of tracking MPP under rapidly changing conditions. Also the HCS method loses it track ability when the wind speed decreases and it has to climb downhill to search the maximum power point. ${ }^{55}$ To overcome these demerits, improved HCS methods are proposed in literature. ${ }^{62,63}$

\subsubsection{Optimum Tip Speed Ratio Control}

Power generated by wind is mostly governed by the tip speed ratio (TSR) thus in this method optimum TSR is determined by measuring the wind speed and rotor speed. Optimum TSR for a given wind turbine is constant regardless of the wind speed $^{54}$ thus maintaining optimum TSR will ensure operation of the turbine at maximum power point. TSR is calculated by measuring the turbine speed and wind speed so it requires an anemometer for the wind speed measurement. The TSR is then compared with the optimum value of TSR, which is stored in the system, and the difference is fed to the controller which in turn adjusts the speed of the generator. ${ }^{55}$ As wind speed is measured continuously by anemometer and updated instantaneously so it provides immediate response to change in wind speed. Fig. 10 shows the working principle of TSR control.

Measuring wind speed along with the additional cost is the major hindrance of this control system. ${ }^{61,64}$ Also the optimum value of TSR is different from system to system so a custom tailored control is needed for individual turbine. Furthermore the optimum operating point may vary significantly with time and atmospheric condition. Factors like icing, dirt and aging decreases the turbine rotor efficiency which is not compensated by the TSR control algorithm. ${ }^{65}$

\subsubsection{Optimum Torque Control}

Similar to optimum TSR control where optimum TSR $\left(\lambda_{\text {opt }}\right)$ ensures maximum exploitation of available wind energy, this method adjusts PMSG torque relative to maximum reference torque of wind turbine at a given wind speed.

Equation (17) can be re-written as

$$
V=\frac{\omega R}{\lambda}
$$

Using equation (46) in equation (16) yields

$$
P=\frac{1}{2} \rho \pi R^{5} \frac{\omega^{3}}{\lambda^{3}} C_{p}
$$

When rotor is rotating at $\lambda_{\text {opt }}, C_{p}=C_{p \max }$. So equation (47) becomes

$$
P_{o p t}=\frac{1}{2} \rho \pi R^{5} \frac{C_{p \max }}{\lambda_{\text {opt }}^{3}} \omega^{3}=K_{\text {opt }} \omega^{3}
$$

Power is also defined as

$$
P=\omega T
$$

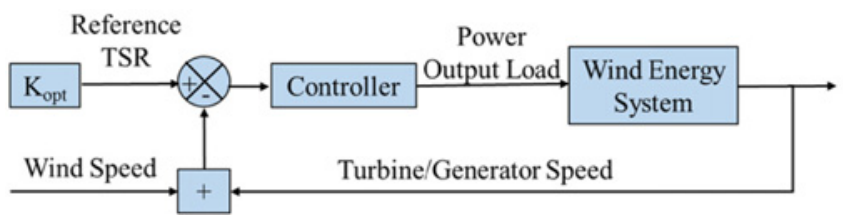

Fig. 10 Block diagram for TSR control

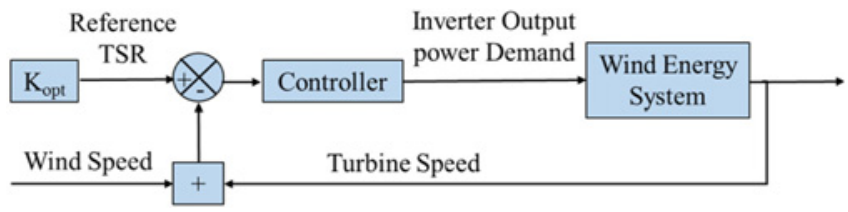

Fig. 11 Block diagram for optimum torque control

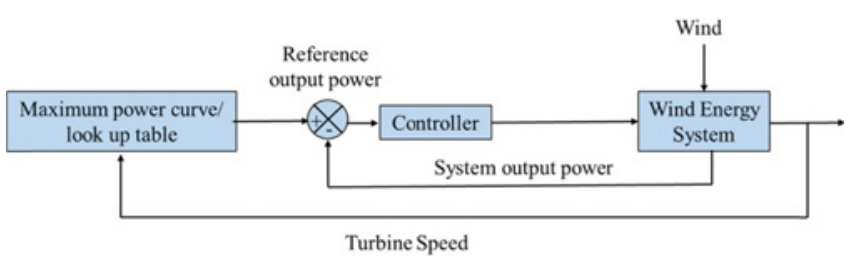

Fig. 12 Block diagram for PSF control

Rearranging (49) we get

$$
T=\frac{P}{\omega}
$$

using equation (50) and (48) we can obtain

$$
T_{o p t}=\frac{1}{2} \rho \pi R^{5} \frac{C_{p \max }}{\lambda_{o p t}^{3}} \omega^{2}=K_{o p t} \omega^{2}
$$

The analytical value obtained by above equation is provided as reference torque to wind turbine. This method is simple, fast and efficient but its efficiency is lower compared with TSR control because it does not measure the wind speed directly. So wind speed changes are not instantly reflected on reference signal. ${ }^{54,55}$ Fig. 11 shows the block diagram of optimal torque control technique.

\subsubsection{Power Signal Feedback}

In this method maximum power tracking is done by reading the current power output and determines the control mechanism to follow the maximum power in look up table obtained via simulation or test result for individual wind turbine. This makes power signal feedback (PSF) control difficult and expensive. ${ }^{6,61}$ Fig. 12 shows the schematic of PSF control.

A functional approach, instead of the look up table can be used where the power coefficient is expressed as function of TSR and blade pitch angle as in equation (42).

The function differs with the wind turbine rotor type so coefficients $c_{1}-c_{6}$ and $x$ in equation (42) can be different for different turbines. The coefficients $\left(c_{1}-c_{6}\right)$ and parameter $\left(\lambda_{i}\right)$ used by ref. [5,66-68] are different. The power coefficient used by ref. [5] are $c_{1}=0.53, c_{2}=151, c_{3}=0.58$, $c_{4}=0.002, c_{5}=13.2, c_{6}=18.4$ and $x$ is 2.14 . The parameter $\left(\lambda_{i}\right)$ in ref. [51] has been defined as in equation (43) while in ref. [5] is defined as

$$
\frac{1}{\lambda_{i}}=\frac{1}{\lambda-0.02 \beta}-\frac{0.03}{1+\beta^{3}}
$$




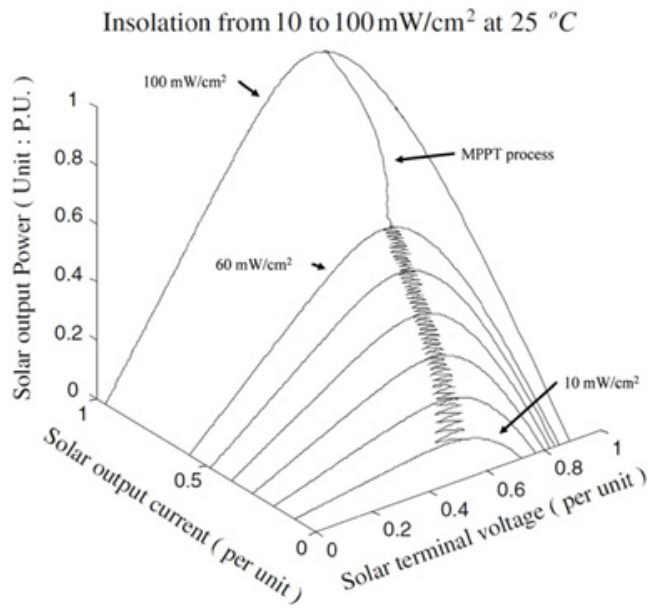

Fig. 13 Maximum power point tracking when insolation changes (redrawn from ref. [66])

Table 1: Solar MPPT techniques

\begin{tabular}{cc}
\hline Methods & Reference \\
\hline P\&O & $67-69$ \\
\hline Incremental conductance & $70-73$ \\
\hline Open circuit voltage & $72,74-76$ \\
\hline Short circuit current & 72,76 \\
\hline Parasitic capacitance & 77 \\
\hline Look up table and curve fitting method & 78,79 \\
\hline
\end{tabular}

\subsubsection{Other Methods}

There are several other novel algorithms proposed in various literature. Researcher in ref. [70] has used Fuzzy logic control, and artificial neural network (ANN) has been implemented in ref. [50,69] for MPP tracking in wind energy systems.

\subsection{MPPT Tracking in PV System}

The characteristic of solar cell is dependent upon the insolation, temperature and array voltage. Thus it is necessary to implement MPPT in order to move the operating voltage close to maximum power point under changing atmospheric conditions.

MPPT in solar is important because it reduces the solar array cost by decreasing the number of solar panels needed to obtain the desired output.

V-I characteristics of the solar array neglecting the internal shunt resistance is given by ref. [50]

$$
I_{0}=I_{g}-I_{\text {sat }}\left\{\exp \left[\frac{q\left(V_{o}+I_{0} R_{S}\right)}{A K T}\right]-1\right\}
$$

here $A$ is dimensionless factor.

The output characteristic of PV array is shown in Fig 13. It shows MPP tracking during varying weather condition.

\subsubsection{Perturb and Observe (P\&O)}

$\mathrm{P} \& \mathrm{O}$ is the most widely used technique because of its simple feedback structure and fewer measured parameters. The basic idea behind $\mathrm{P} \& \mathrm{O}$ is discussed in earlier section. $\mathrm{P} \& \mathrm{O}$ for solar system involves periodically increase or decrease of solar voltage and look for the subsequent power change. If a given perturbation leads to an increase in the array power then the subsequent perturbation is done in the same direction otherwise perturbation is done in opposite

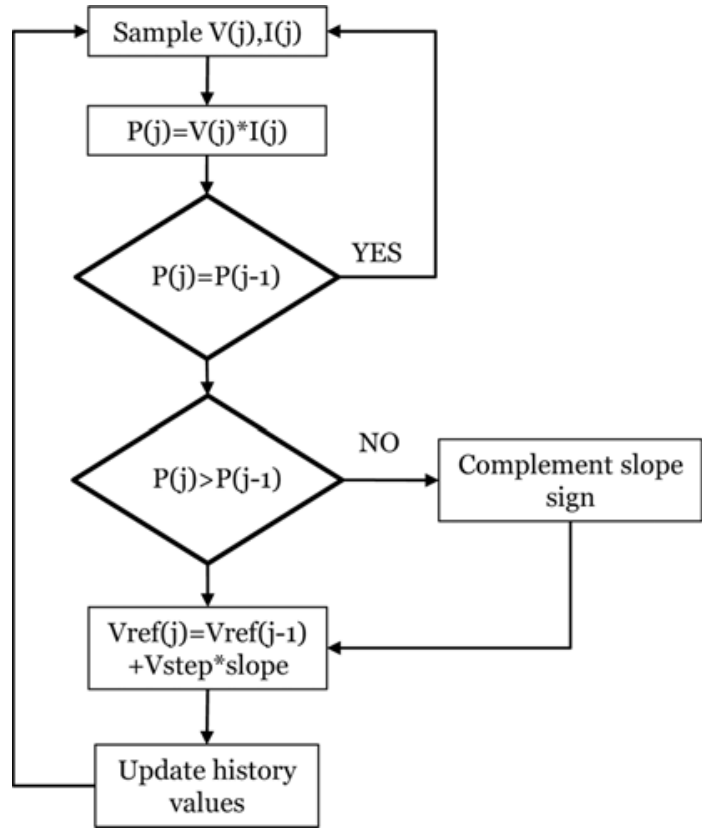

Fig. 14 Flow chart of P\&O algorithm for PV system

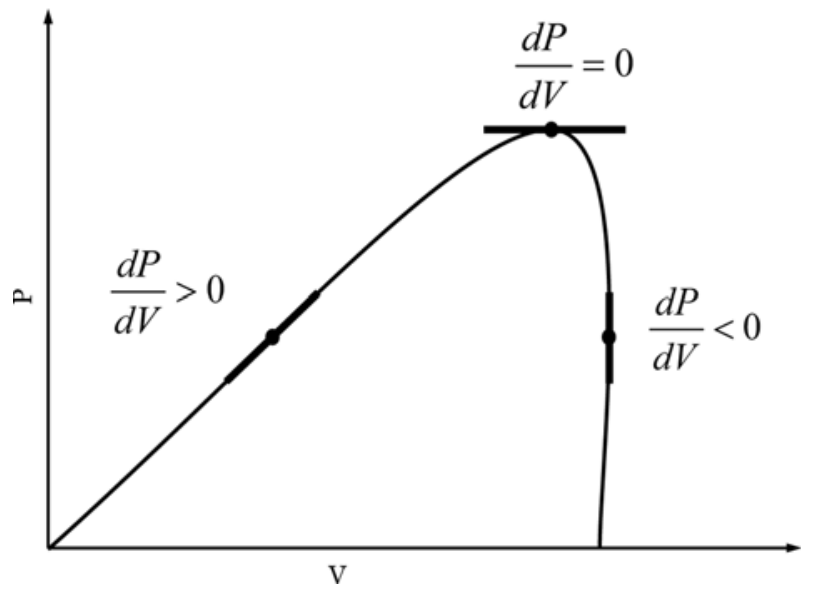

Fig. 15 Variation of $\mathrm{dP} / \mathrm{dV}$

direction. ${ }^{80}$ As discussed earlier, MPPT for solar using P\&O works better than that in wind because the solar irradiance change is relatively slower compared with wind. The P\&O flow chart is shown in Fig. 14.

\subsubsection{Incremental Conductance Method}

Incremental conductance (IC) method is an alternative to $\mathrm{P} \& \mathrm{O}$ method where solar array terminal voltage can be adjusted relative to the MPP voltage by measuring the incremental and instantaneous array conductance $(d I / d V$ and $I / V)$. It seems to overcome the limitations of $\mathrm{P} \& \mathrm{O}$ by using incremental conductance to compute the sign of $d P / d V$ without perturbation. It does this by using expression $d P / d V=0$ which represents MPP as shown in Fig. 15.

$$
\begin{gathered}
\frac{d P}{d V}=I \frac{d V}{d V}+V \frac{d I}{d V}=0 \\
\frac{d I}{d V}=-\frac{1}{V}
\end{gathered}
$$

Analyzing (52) and (53) $d P / d V$ is negative when the current 
operating point is on the right of MPPT and positive when it is to the left of MPP as shown in Fig. 15.

IC method offers good performance under rapidly changing atmospheric conditions. ${ }^{68}$ It is also capable of knowing whether the MPP has reached so does not oscillate like P\&O method. ${ }^{71}$ In other hand IC method is relatively more complex than P\&O method. It requires four sensors to perform the computation thus is expensive and also requires more computational time which results in power loss. ${ }^{70-72}$ Although IC is relatively faster than $\mathrm{P} \& \mathrm{O}$ it is still slow and inaccurate in faster variations of solar insolation. ${ }^{75,81}$

\subsubsection{Parasitic Capacitance Algorithm}

Parasitic capacitance method is refinement of the IC method, which considers the parasitic junction capacitances (PJC) of the solar cell into account. ${ }^{71,72}$ PJC in PV cell occurs as a result of charge accumulation in p-n junction area and the inductance associated to the connections of PV cells. ${ }^{82}$ The parasitic capacitance reduces the error signal when operating outside the MPP thus it slows down the system dynamics. ${ }^{77}$ Parasitic capacitance is modeled as a capacitor that is parallel connected to each PV cell in a module. Therefore parallel connection of module increases the amount of parasitic capacity of MPPT which results in increased efficiency of parasitic capacitance algorithm to reach maximum value in PV systems with numerous parallel-connected modules. $^{71,82}$

\subsubsection{Look Up Table and Curve Fitting Method}

In look up table method the PV generated voltage and current are compared with the current and voltage at MPP in a look up table which is previously stored in the control system under given climatic conditions. ${ }^{78}$ It employs similar algorithm to power signal feedback discussed in MPPT for wind systems.

In a curve fitting method, a functional or a numerical approach is used instead of a look up table. A fitted equation to define PowerVoltage (P-V) characteristics of a PV is discussed in the paper. ${ }^{79}$

$$
P_{p v}=a V_{P V}^{3}+b V_{P V}^{2}+c V_{P V}+d
$$

Here $a, b, c$, and $d$ are coefficients determined by sampling values of PV voltage. The voltage at maximum power is obtained can be found using

$$
V_{M P P}=\frac{-b \pm \sqrt{b^{2}-3 a c}}{3 a}
$$

The process can be repeated in each milliseconds to find more accurate MPP. ${ }^{83}$ The disadvantage of this method is that it requires knowledge of the physical parameters relating to the cell material for all climatological conditions. Thus large memory capacity for calculation might be needed.

\subsubsection{Open Circuit Voltage based MPPT Technique}

The power at maximum power point is defined as

$$
P_{M P P}=I_{M P P} V_{M P P}
$$

As there exists a single point where maximum power is obtained, knowing the value of any one of $I_{M P P}$ or $V_{M P P}$, MPP can be tracked. ${ }^{72}$
This technique assumes that the ratio of MPP voltage and open circuit voltage is weakly affected by the solar radiation and temperature $\mathrm{r}^{75,76}$ i.e.

$$
V_{M P P} \approx K_{o c} V_{o c}
$$

Where $K_{o c}$ is the voltage factor which can be calculated by analyzing the PV system for wide range of solar radiations and temperature and generally varies between 0.71 and $0.92 .^{72,84}$

The major problem associated with this technique is the estimation of $V_{o c}$ which require periodic disconnection of the PV module. ${ }^{78}$ In order to measure $V_{o c}$ the PV system is open-circuited for a fraction of second and reading for $V_{o c}$ is taken. $V_{M P P}$ is then calculated using (57). This process is repeated in every few seconds to update value of $V_{M P P .}{ }^{71,81}$ An alternative way is to measure on a separate PV cell called as pilot cell which can represent the characteristics of the PV array. ${ }^{72,84}$

\subsubsection{Short Circuit Current based MPPT Technique}

This technique has similar approach to open circuit voltage technique except it assumes a linear dependency between MPP current and short circuit current. ${ }^{76}$

$$
I_{M P P} \approx K_{s c} I_{s c}
$$

where $K_{s c}$ is the current factor and its value can be calculated by analyzing the PV system for wide range of solar radiations and temperature and it generally varies between 0.64 and $0.85 .^{72}$

\subsubsection{Other Techniques}

Karabacak and $\mathrm{Cetin}^{85}$ discussed in detail the application of neural network in solar-wind hybrid in literature. Fuzzy logic has been used in literature. ${ }^{84,86}$ Various novel methods proposed and discussed by several authors. ${ }^{55,72,83}$ They have proposed more than 20 different techniques for MPPT tracking in solar system but most of those techniques could be costly, difficult to implement, and may not be stable enough. ${ }^{67,74}$

\section{Battery Modeling}

Batteries have a significant role in off grid HRES and have large share in initial cost. Batteries are used as a backup option to store the power when the power production excesses the demand. The supply from the battery is needed during peak hours when power demand is higher than the production. In some model of HRES batteries are used as a storage buffer, and all the electricity is supplied through battery.

Batteries used in RES have different performance characteristics compared with batteries used in traditional applications and in electric vehicles. Because of the stochastic nature of the renewable energy resources the battery may experience frequent deep cycles and irregular charging patterns. Also due to seasonal variations the battery may experience a low state of charge (SOC) for extended period. This inconsistency in charging and discharging causes decrease in the battery life. The diminished battery life causes significant impact in the overall life cycle cost of the HRES. If we consider a standalone PV 


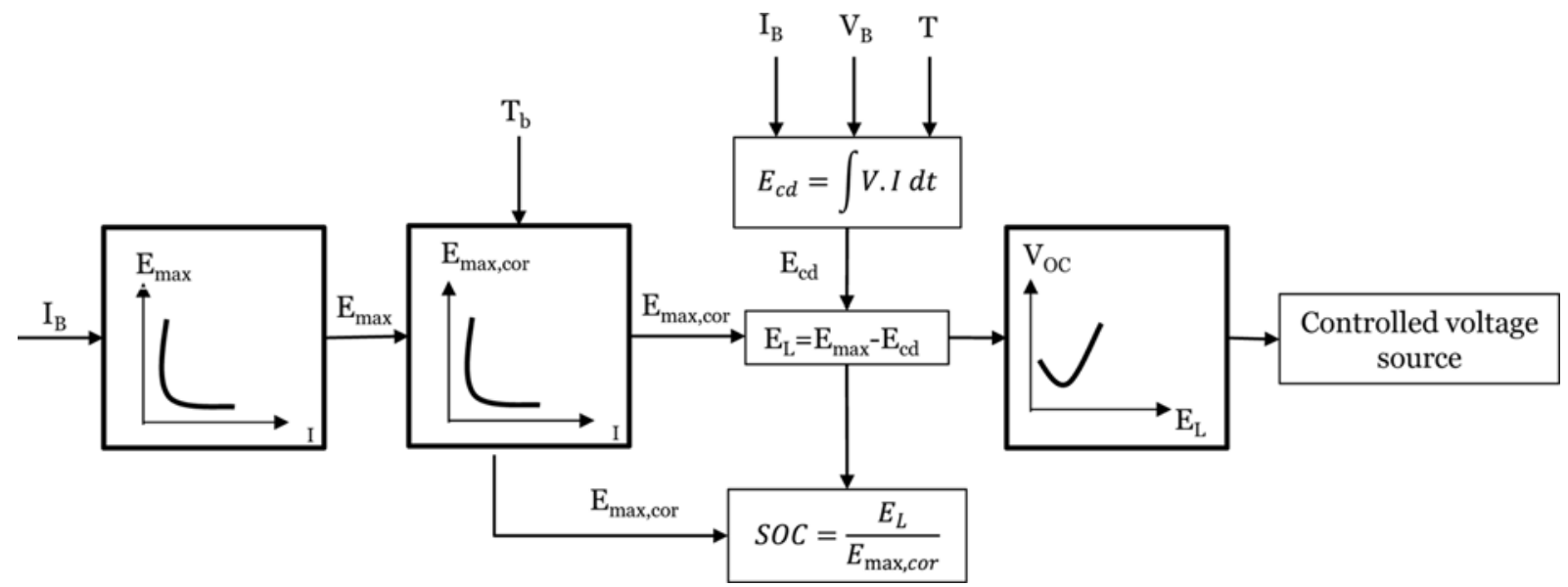

Fig. 17 Block diagram for determining $\mathrm{V}_{\mathrm{oc}}$ and SOC (Redrawn from ref. [5])

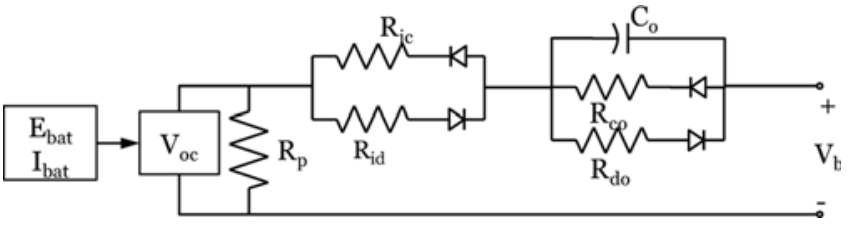

Fig. 16 Dynamic model of lead acid batteries

system batteries can account for more than $40 \%$ of the life cycle cost. ${ }^{87}$ This can give us an idea on the share of the battery in the total life cycle cost. Increasing the lifecycle of the battery will result in the significant improvement in reliability and decrease in the lifecycle cost.

Battery's lifetime depends upon the rate of energy consumption from the system. The easiest way is to increase the battery life could be decreasing the battery consumption rate - which is not always practical in case of HRES. During the period of high consumption the effective capacity of battery degrades and therefore decreases the life. During period without energy consumptions the battery can recover some of its lost capacity so the life is lengthened. ${ }^{88}$

Peukert's Law is widely used to predict the battery discharge considering the nonlinear properties of the battery. Mathematically Peukert's law is stated as

$$
t_{\text {discharge }}=H\left(\frac{C}{I H}\right)^{k}
$$

where $t$ is the battery discharge time, $C$ is battery capacity (Amperehour value), $I$ is the current drawn, $H$ is rated discharge time, $k$ is Peukert's coefficient. The Peukert's coefficient is an empirical value which can be determined by formula

$$
k=\frac{\log T_{2}-\log T_{1}}{\log I_{1}-\log I_{2}}
$$

where $I_{1}$ and $I_{2}$ are the two discharge current rates, and $T_{1}$ and $T_{2}$ are the corresponding discharge duration. The battery capacity decreases with time that means the time for charging and discharging will change. So the value of $k$ should be accessed after certain number of recharge cycles. The value of $k$ for lead acid battery is 1.3-1.4.

The charging time for a completely discharged battery is given by

$$
t_{\text {charging }}=\frac{\text { Ampere hour of battery }}{\text { Charging Current }}
$$

\subsection{Mathematical Modeling}

The dynamic model of battery modeling by Dürr ${ }^{89}$ is shown in Fig. 16 , which considers the non-linear nature of the battery discharge and determines the open circuit voltage $\left(V_{o c}\right)$.

Here $R_{p}$ is the self-discharge resistance, which takes into account of a small self-discharge leakage current, $R_{i c}$ and $R_{i d}$ are the internal resistance which compensates resistance of the electrolyte and the battery plates, $R_{c o}$ and $R_{d o}$ are the voltage drop for the charge and discharge process and $C_{o}$ represents the double layer capacitance behavior of the battery during charge and discharge.

The open circuit voltage is a non-linear function of battery temperature $(T)$, discharge current $\left(I_{B}\right)$ and energy drawn from the battery $\left(E_{c d}\right)$. This model uses initial battery current $\left(I_{B}\right)$ to predict the maximum available energy. The remaining battery energy and state of charge (SOC) is calculated dynamically by subtracting form the initial energy. The block diagram for determining $V_{o c}$ and SOC is shown in Fig. 17.

Diaf ${ }^{90}$ compared the powered demand and power generation by wind and solar to determine the state of charge and storage capacity. In their system the wind power is directly sent to load through an UPS. Unlike solar which is available during day only, wind can be available throughout the day. So there can be three cases:

a. Where wind alone can meet the power demand i.e. $P_{w g}(t) \geq P_{\text {load }}(t)$. Excess power if available would be used in charging the battery. The storage capacity at any given time $(\mathrm{t})$ is expressed as

$$
C_{b a t}(t)=C_{b a t}(t-1)+\left(P_{p v}(t)+P_{w g}(t)-P_{\text {load }}(t) \eta_{c a d}\right) \Delta t \eta_{c h a}
$$

where $C_{b a l}(\mathrm{t})$ and $C_{b a r}(\mathrm{t}-1)$ are the available battery capacity at time (t) and $(\mathrm{t}-1)$. $P_{p v}$ is power generated by $\mathrm{PV}, P_{w g}$ is power generated by wind turbine generator, $P_{\text {load }}(\mathrm{t})$ is power consumed at load $t, t$ is simulation time step ( $\left.\Delta t=1 \mathrm{hrs}\right), \eta_{\text {cad }}$ is efficiency of $\mathrm{AC} / \mathrm{DC}$ converter and $\eta_{\text {cha }}$ is battery charging efficiency which depends upon charging current and may vary from $0.65-0.85 .{ }^{91}$

b. Wind alone cannot meet the power demand but combining with PV can, i.e., $\left(\eta_{i n v} P_{w g}(t)+P_{p v}(t)\right) \geq P_{\text {load }}(t)$. In such case the excess power if available is used in charging the battery. Battery storage capacity in such case is given by:

$$
C_{b a t}(t)=C_{b a t}(t-1)+\left(P_{p v}(t)-\left(\frac{P_{\text {load }}(t)-P_{w g}(t)}{\eta_{\text {inv }}}\right)\right) \Delta t \eta_{\text {cha }}
$$


c. Total energy generated cannot meet the load demand then the battery is in discharge process (i.e. $\eta_{\text {inv }} P_{w g}(t)+P_{p v}(t)<P_{\text {load }}(t)$ )

$$
C_{b a t}(t)=C_{b a t}(t-1)+\frac{1}{\eta_{d e c h}}\left(P_{p v}(t)-\left(\frac{P_{l o a d}(t)-P_{w g}(t)}{\eta_{i n v}}\right)\right) \Delta t
$$

where $\eta_{\text {dech }}$ is battery discharge efficiency (which is equal to $1^{92}$ ), $\eta_{\text {inv }}$ is inverter efficiency, $C$ is capacity of battery at any time $t, C_{b a t}(t)$ is constrained by $C_{b a t \text { min }} \leq C_{b a t}(t) \leq C_{b a t \text { max }}$ where $C_{b a t \text { min }}$ and $C_{b a t \text { max }}$ are minimum and maximum allowable battery capacity.

Optimum capacity $\left(C_{\text {batn }}\right)$ can be determined by

$$
C_{b a t \min }=D O D \cdot C_{b a t n}
$$

where $D O D$ is depth of discharge in percentage.

The battery bank is sized on the basis of days of autonomy, which is the number of days battery bank can supply the load with absence of power. Maximum depth of discharge, temperature, rated battery capacity and battery life are other factors that affect the battery selection. Battery capacity with regards to the depth of discharge can be calculated as

$$
C_{b a t}=\frac{P_{\text {load }} \times D_{s}}{D O D_{\max } \times \eta_{t}}
$$

where $C_{b a t}$ is battery capacity in Amp-hrs, $P_{\text {load }}$ is load in ampere hour.

Bin et al. ${ }^{91}$ used the following model to estimate charge of battery at any time ' $t$ '. When the battery is at charging state

$$
E_{B}(t)=E_{B}(t-1)(t-\sigma)+\left(E_{G A}(t)-\frac{E_{L}(t)}{\eta_{\text {inv }}}\right) \cdot \eta_{\text {batt }}
$$

And while discharging (assuming discharge efficiency to be 1)

$$
E_{B}(t)=E_{B}(t-1)(t-\sigma)-\left(\frac{E_{L}(t)}{\eta_{\text {inv }}}-E_{G A}(t)\right) \cdot \eta_{\text {batt }}
$$

where $E_{B}(t)$ and $E_{B}(t-1)$ is battery charge at time $t$ and $(t-1)$ respectively, $\sigma$ is hourly self-discharge rate, $E_{G A}(t)$ is the total energy generated by combined PV and wind generator after energy loss controller, $E(\mathrm{~L})$ is load at time $t$, and $\eta_{i n v}$ and $\eta_{\text {batt }}$ are the efficiency of inverter and charging efficiency of battery bank.

The battery bank should meet the following condition.

$$
E_{B \min } \leq E_{B(t)} \leq E_{B \max }
$$

Here the maximum charge quantity of the battery bank $E_{B \text { max }}$ is the rated nominal capacity of battery bank and $E_{B \text { min }}$ is the minimum charge of battery determined by depth of discharge (DOD) such that;

$$
E_{B \min }=(1-D O D) \cdot C_{\text {batt }}
$$

\section{Control of Hybrid Energy System}

The dynamic interaction between the power electronic interface of renewable energy sources leads to problems of stability and power quality in the system, which makes HES control difficult and complex. ${ }^{2}$ A hybrid energy system can be standalone or grid connected.
Standalone systems need to have generation and storage capacity large enough to handle the load while in a grid connected system the storage device can be relatively smaller as deficient power can be obtained from the grid. A grid connected hybrid can supply electricity to both load and the utility grid. However, when connected to grid, proper power electronic controllers are required to control voltage, frequency and harmonic regulations, and load sharing. ${ }^{13}$ The performance analysis of HES can only be evaluated after performance analysis of individual system. MPPT tracking is to be done for individual subsystems as found in literature.

During operation hybrid wind-solar system is subjected to fluctuating wind speeds and solar insolation as well as to varying load demand. Hence a controller is essential to determine how much energy is available from each component and how much to use of it. The operation policy for autonomous wind-solar hybrid system should employ the available energy from the wind turbine and solar panel in each sub period to use first and excess energy to be stored in batteries. If the renewable energy is not sufficient to supply the load in a given sub period then energy is drawn from battery storage first and then through diesel generator (if available). In case of systems where diesel generator are available, batteries act as fuel saver as batteries are used prior to diesel engine. ${ }^{10}$ The operation policy in case of grid connected hybrid system should exploit renewable energy first and excess energy if available should be stored in batteries. However if excess energy is still available then it should be sold to the grid. If renewable energy is not sufficient to supply the load in a given sub period then batteries should be employed first and grid electricity should be used if deficiency still exists. The battery in grid connected system store the surplus power from power generation system, so only small power from the grid is needed.

\section{Conclusions}

Approximately one-fifth of the global populations are living without electricity in the world. In developing countries of Asia, it is estimated that almost one third of total population are deprived of electricity. An alternative to the grid connected power is the renewable energy based off-grid power system.

Focusing on the three top most used renewable energy sources, we have presented a summary of mathematical modeling of various renewable power systems. Non-linear characteristics of wind power system and PV system such as the power, voltage and current are summarized for maximum power point tracking. Various MPPT techniques and modeling of storage device were presented.

\section{ACKNOWLEDGEMENT}

This work was supported by grants from the National Research Foundation of Korea (NRF), funded by the Korean government (MEST) (No. 2011K1A5A2000071, 2012K1A3A9A01027846), and by cluster projects of Engineering Research Institute in the School of Engineering of Seoul National University and third stage of the Brain Korea 21 Plus Project in 2013. 


\section{REFERENCES}

1. Dornfeld, D., "Moving Towards Green and Sustainable Manufacturing,” Int. J. Precis. Eng. Manuf.-Green Tech., Vol. 1, No. 1, pp. 63-66, 2014.

2. Nema, P., Nema, R. K., and Rangnekar, S., "A Current and Future State of Art Development of Hybrid Energy System using Wind and PV-solar: A Review," Renewable and Sustainable Energy Reviews, Vol. 13, No. 8, pp. 2096-2103, 2009.

3. Stroe, D., Stan, A., Visa, I., and Stroe, I., "Modeling and Control of Variable Speed Wind Turbine Equipped with PMSG,” 2011.

4. Ahn, S. -H., "An Evaluation of Green Manufacturing Technologies Based on Research Databases,” Int. J. Precis. Eng. Manuf.-Green Tech., Vol. 1, No. 1, pp. 5-9, 2014.

5. Kalantar, M. and Mousavi G, S. M., "Dynamic Behavior of a StandAlone Hybrid Power Generation System of Wind Turbine, Microturbine, Solar Array and Battery Storage," Applied Energy, Vol. 87, No. 10, pp. 3051-3064, 2010.

6. Soetedjo, A., Lomi, A., and Mulayanto, W. P., "Modeling of Wind Energy System with MPPT Control," International Conference on Electrical Engineering and Informatics (ICEEI), pp. 1-6, 2011.

7. Adzic, E., Ivanovic, Z., Adzic, M., and Katic, V., "Maximum Power Search in Wind Turbine Based on Fuzzy Logic Control," Acta Polytechnica Hungarica, Vol. 6, No. 1, pp. 131-149, 2009.

8. Ahn, S. H., Lee, K. T., Bhandari, B., Lee, G. Y., Lee, C. S., and Song, C. K., "Formation Strategy of Renewable Energy Sources for High Mountain Off-grid System Consideting Sustainability," J. Korean Soc. Precis. Eng., Vol. 29, No. 9, pp. 958-963, 2012.

9. Bekele, G. and Palm, B., "Feasibility Study for a Standalone SolarWind-Based Hybrid Energy System for Application in Ethiopia," Applied Energy, Vol. 87, No. 2, pp. 487-495, 2010.

10. Chedid, R. and Rahman, S., "Unit Sizing and Control of Hybrid Wind-Solar Power Systems," IEEE Transactions on Energy Conversion, Vol. 12, No. 1, pp. 79-85, 1997.

11. Chedid, R. B., Karaki, S. H., and El-Chamali, C., "Adaptive Fuzzy Control for Wind-Diesel Weak Power Systems," IEEE Transactions on Energy Conversion, Vol. 15, No. 1, pp. 71-78, 2000.

12. Kane, M., "Small Hybrid Solar Power System," Energy, Vol. 28, No. 14, pp. 1427-1443, 2003.

13. Dali, M., Belhadj, J., and Roboam, X., "Hybrid solar-Wind System with Battery Storage Operating in Grid-Connected and Standalone Mode: Control and Energy Management - Experimental Investigation,” Energy, Vol. 35, No. 6, pp. 2587-2595, 2010.

14. Ram Prabhakar, J. and Ragavan, K., "Power Management Based Current Control Technique for Photovoltaic-Battery Assisted WindHydro Hybrid System," International Journal of Emerging Electric Power Systems, Vol. 14, No. 4, pp. 351-362, 2013.

15. Diaf, S., Notton, G., Belhamel, M., Haddadi, M., and Louche, A.,
"Design and Techno-Economical Optimization for Hybrid PV/Wind System under Various Meteorological Conditions,” Applied Energy, Vol. 85, pp. 968-987, 2008.

16. Jeon, Y. -J., Kim, D. -S., and Shin, Y -E., "Study of Characteristics of Solar Cells through Thermal Shock and High-Temperature and High-Humidity Testing,” Int. J. Precis. Eng. Manuf., Vol. 15, No. 2, pp. 355-360, 2014.

17. Hashimoto, S., Yachi, T., and Tani, T., "A New Stand-Alone Hybrid Power System with Wind Turbine Generator and Photovoltaic Modules for a Small-Scale Radio Base Station,” IEEJ Transactions on Power and Energy, Vol. 125, No. 11, pp. 1041-1046, 2005.

18. Sharaf, A. M. and El-Sayed, M. A. H., "A Novel Hybrid Integrated Wind-PV Micro Co-Generation Energy Scheme for Village Electricity," Proc. of IEEE International Electric Machines and Drives Conference(IEMDC '09), pp. 1244-1249, 2009.

19. Bakos, G. C., "Feasibility Study of a Hybrid Wind/Hydro PowerSystem for Low-Cost Electricity Production," Applied Energy, Vol. 72, No. 3-4, pp. 599-608, 2002.

20. Bekele, G. and Tadesse, G., "Feasibility Study of Small Hydro/PV/ Wind Hybrid System for Off-Grid Rural Electrification in Ethiopia," Applied Energy, Vol. 97, pp. 5-15, 2012.

21. Saheb-Koussa, D., Haddadi, M., and Belhamel, M., "Economic and Technical Study of a Hybrid System (wind-photovoltaic-diesel) for Rural Electrification in Algeria," Applied Energy, Vol. 86, No. 7-8, pp. 1024-1030, 2009.

22. Fadaeenejad, M., Radzi, M. A. M., AbKadir, M. Z. A., and Hizam, H., "Assessment of Hybrid Renewable Power Sources for Rural Electrification in Malaysia," Renewable and Sustainable Energy Reviews, Vol. 30, pp. 299-305, 2014.

23. Goodbody, C., Walsha, E., McDonnella, K. P., and Owendeb, P., "Regional Integration of Renewable Energy Systems in Ireland The Role of Hybrid Energy Systems for Small Communities," International Journal of Electrical Power \& Energy Systems, Vol. 44, No. 1, pp. 713-720, 2013.

24. Akikur, R. K., Saidur, R., Ping, H. W., and Ullah, K. R., "Comparative Study of Stand-Alone and Hybrid Solar Energy Systems Suitable for Off-Grid Rural Electrification: A review," Renewable and Sustainable Energy Reviews, Vol. 27, pp. 738-752, 2013.

25. Djamel, L. and Abdallah, B., "Power Quality Control Strategy for Grid-Connected Renewable Energy Sources using PV Array, Wind Turbine and Battery," Proc. of 2013 Fourth International Conference on Power Engineering, Energy and Electrical Drives(POWERENG), pp. 1671-1675, 2013.

26. Meshram, S., Agnihotri, G., and Gupta, S., "Performance Analysis of Grid Integrated Hydro and Solar Based Hybrid Systems," Advances in Power Electronics, Vol. 2013, pp. 1-7, 2013.

27. Ismail, M. S., Moghavvemi, M., and Mahlia, T. M. I., "Design of an Optimized Photovoltaic and Microturbine Hybrid Power System for 
a Remote Small Community: Case Study of Palestine," Energy Conversion and Management, Vol. 75, No. 11, pp. 271-281, 2013.

28. Daud, A. -K. and Ismail, M. S., "Design of Isolated Hybrid Systems Minimizing Costs and Pollutant Emissions," Renewable Energy, Vol. 44, pp. 215-224, 2012.

29. Ismail, M. S., Moghavvemi, M., and Mahlia, T. M. I., "Technoeconomic Analysis of an optimized Photovoltaic and Diesel Generator Hybrid Power System for Remote Houses in a Tropical Climate," Energy Conversion and Management, Vol. 69, pp. 163173, 2013.

30. Menshsari, A., Ghiamy M., Mir Mousavi, M. M., and Bagal, H. A., "Optimal Design of hybrid Water-Wind-Solar System based on Hydrogen Storage and Evaluation of Reliability Index of System using Ant Colony Algorithm," International Research Journal of Applied and Basic Science, Vol. 4, No. 11, pp. 3582-3600, 2013.

31. Vitali, D. and Ricci, R., "Design, Testing and Simulation of Hybrid Wind-Solar Energy Systems,” 2013.

32. Saha, N. C., Acharjee, S., Mollah, M. A. S., Rahman, K. T., Rafi, F. H. M., and et al., "Modeling and Performance Analysis of a Hybrid Power System," Proc. of International Conference on Informatics, Electronics \& Vision(ICIEV), pp. 1-5, 2013.

33. Suha Yazici, M., Yavasoglu, H. A., and Eroglu, M., “A Mobile OffGrid Platform Powered with Photovoltaic/Wind/Battery/Fuel Cell Hybrid Power Systems," International Journal of Hydrogen Energy, Vol. 38, No. 26, pp. 11639-11645, 2013.

34. Bhandari, B., "Design and Evaluaion of Tri-hybrid Renewable Energy System (THRES)," Ph. D. Thesis, Department of Mechanical \& Aerospace Engineering, Seoul National Univ., 2014.

35. Karaki, S. H., Chedid, R. B., and Ramadan, R., "Probabilistic Performance Assessment of Autonomous Solar-Wind Energy Conversion Systems," IEEE Transactions on Energy Conversion, Vol. 14, No. 3, pp. 766-772, 1999.

36. Markvart, T., "Solar Electricity,” John Wiley \& Sons, pp. 5-19, 2000.

37. Hong, S., Bae, J., Koo, B., Chang, I., Cho, G. Y., and et al., "Nanostructuring methods for Enhancing Light Absorption Rate of Si-based Photovoltaic Devices: A review," Int. J. Precis. Eng. Manuf.-Green Tech., Vol. 1, No. 1, pp. 67-74, 2014.

38. Kanellos, F., Tsouchnikas, A. I., and Hatziargyriou, N., "Micro-grid Simulation during Grid-Connected and Islanded Modes of Operation," International Conference on Power Systems Transients, Paper No. IPST05-113, 2005.

39. Ye, L., Sun, H. B., Song, X. R., and Li, L. C., "Dynamic Modeling of a Hybrid Wind/Solar/Hydro Microgrid in EMTP/ATP," Renewable Energy, Vol. 39, No. 1, pp. 96-106, 2012.

40. Salam, Z., Ishaque, K., and Taheri, H., "An Improved Two-Diode Photovoltaic (PV) Model for PV System," Proc. of Joint International Conference on Power Electronics, Drives and Energy Systems(PEDES) \& 2010 Power India, pp. 1-5, 2010.
41. Zhou, W., Yang, H., and Fang, Z., "A Novel Model for Photovoltaic Array Performance Prediction,” Applied Energy, Vol. 84, No. 12, pp. 1187-1198, 2007.

42. Betz, A., "Introduction to the theory of flow machines," Oxford: Pergamon Press, 1966.

43. Lu, L., Yang, H., and Burnett, J., "Investigation on Wind Power Potential on Hong Kong Islands-an Analysis of Wind Power and Wind Turbine Characteristics," Renewable Energy, Vol. 27, No. 1, pp. 1-12, 2002.

44. Yang, H., Wei, Z., and Chengzhi, L., "Optimal Design and TechnoEconomic Analysis of a Hybrid Solar-Wind Power Generation System,” Applied Energy, Vol. 86, No. 2, pp. 163-169, 2009.

45. Chedid, R., Mrad, F., and Basma, M., "Intelligent Control of a Class of Wind Energy Conversion Systems," IEEE Transactions on Energy Conversion, Vol. 14, No. 4, pp. 1597-1604, 1999.

46. Boukhezzar, B. and Siguerdidjane, H., "Comparison between Linear and Nonlinear Control Strategies for Variable Speed Wind Turbine Power Capture Optimization," Ecologic Vehicles Renewable Energies, pp. 26-29, 2009.

47. Boukhezzar, B. and Siguerdidjane, H., "Nonlinear Control with wind Estimation of a DFIG Variable Speed Wind Turbine for Power Capture Optimization," Energy Conversion and Management, Vol. 50, No. 4, pp. 885-892, 2009.

48. Shi, W., Kim, C. -W., Chung, C. -W., and Park, H. -C., "Dynamic Modeling and Analysis of a Wind Turbine Drivetrain using the Torsional Dynamic Model," Int. J. Precis. Eng. Manuf., Vol. 14, No. 1, pp. 153-159, 2013.

49. Bait, A. F. and Brennan, F., "The Modelling, Simulation and Control of a $50 \mathrm{~kW}$ Vertical Axis Wind Turbine," Asian Transactions on Engineering, Vol. 2, No. 4, pp. 14-23, 2012.

50. Hong, C. -M., Chen, C. -H., and Tu, C. -S., "Maximum Power Point Tracking-Based Control Algorithm for PMSG wind Generation System without Mechanical Sensors," Energy Conversion and Management, Vol. 69, pp. 58-67, 2013.

51. Samanvorakij, S. and Kumkratug, P., "Modeling and Simulation PMSG based on Wind Energy Conversion System in MATLAB/ SIMULINK," Proc. of Second Intl. Conf. on Advances in Electronics and Electrical Engineering, pp. 37-41, 2013.

52. Haque, M. E., Negnevitsky, M., and Muttaqi, K. M., "A Novel Control Strategy for a Variable Speed Wind Turbine with a Permanent Magnet Synchronous Generator," IEEE Transactions on Industry Applications, Vol. 46, No. 1, pp. 1-8, 2008.

53. Hemeida, A. M., Farag, W. A., and Mahgoub, O. A., "Modeling and Control of Direct Driven PMSG for Ultra Large Wind Turbines," World Academy of Science, Engineering and Technology, Vol. 59, pp. 621-627, 2011.

54. Abdullah, M. A., Yatim, A. H. M., and Chee Wei, T., "A Study of Maximum Power Point Tracking Algorithms for Wind Energy 
system," Proc. of IEEE First Conference on Clean Energy and Technology(CET), pp. 321-326, 2011.

55. Raza Kazmi, S. M., Goto, H., Guo, H. -J., and Ichinokura, O., "Review and Critical Analysis of the Research Papers Published Till Date on Maximum Power Point Tracking in Wind Energy Conversion System," IEEE Energy Conversion Congress and Exposition(ECCE), pp. 4075-4082, 2010.

56. Sarvi, M. and Azarbara, S., "A Novel Maximum Power Point Tracking Method Based on Extension Theory for Wind Energy Conversion System," International Journal of Computer Science \& Engineering Technology(IJCSET), Vol. 3, No. 8, pp. 294-303, 2012.

57. Camblong, H., Martinez de Alegria, I., Rodriguez, M., and Abad, G., "Experimental Evaluation of Wind Turbines Maximum Power Point Tracking Controllers," Energy Conversion and Management, Vol. 47, No. 18-19, pp. 2846-2858, 2006.

58. Tafticht, T., Agbossou, K., Cheriti, A., and Doumbia, M. L., "Output Power Maximization of a Permanent Magnet Synchronous Generator Based Stand-alone Wind Turbine," IEEE International Symposium on Industrial Electronics, pp. 2412-2416, 2006.

59. Lee, C. -Y., Shen, Y. -X., Cheng, J. -C., Chang, C. -W., and Li, Y. Y., "Optimization Method based MPPT for Wind Power Generators," World Academy of Science, Engineering and Technology, Vol. 60, pp. 169-172, 2009.

60. Hui, J. and Bakhshai, A., "A Fast and Effective Control Algorithm for Maximum Power Point Tracking in Wind Energy Systems," Proc. of the World Wind Energy Conference, 2008.

61. Quincy, W. and Liuchen, C., "An Intelligent Maximum Power Extraction Algorithm for Inverter-Based Variable Speed Wind Turbine Systems," IEEE Transactions on Power Electronics, Vol. 19, No. 5, pp. 1242-1249, 2004.

62. Raza Kazmi, S. M., Goto, H., Guo, H. -J., and Ichinokura, O., “A Novel Algorithm for Fast and Efficient Speed-Sensorless Maximum Power Point Tracking in Wind Energy Conversion Systems," IEEE Transactions on Industrial Electronics, Vol. 58, No. 1, pp. 29-36, 2011.

63. Agarwal, V., Aggarwal, R. K., Patidar, P., and Patki, C., “A Novel Scheme for Rapid Tracking of Maximum Power Point in Wind Energy Generation Systems," IEEE Transactions on Energy Conversion, Vol. 25, No. 1, pp. 228-236, 2010.

64. Ermis, M., Ertan, H. B., Akpinar, E., and Ulgut, F., "Autonomous Wind Energy Conversion System with a Simple Controller for Maximum-Power Transfer," IEE Proc. of B, Electric Power Applications, Vol. 139, No. 5, pp. 421-428, 1992.

65. Kot, R., Rolak, M., and Malinowski, M., "Comparison of Maximum Peak Power Tracking Algorithms for a Small Wind Turbine," Mathematics and Computers in Simulation, Vol. 91, pp. 29-40, 2013.

66. Hua, C. and Lin, J., "A Modified Tracking Algorithm for Maximum Power Tracking Of Solar Array," Energy Conversion and
Management, Vol. 45, No. 6, pp. 911-925, 2004.

67. Hong, C. -M., Ou, T. -C., and Lu, K. -H., "Development of Intelligent MPPT (maximum power point tracking) Control for a Grid-Connected Hybrid Power Generation System," Energy, Vol. 50, pp. 270-279, 2013.

68. Hua, C. and Shen, C., "Study of Maximum Power Tracking Techniques and Control of DC/DC Converters for Photovoltaic Power System," Proc. of $29^{\text {th }}$ Annual IEEE Power Electronics Specialists Conference(PESC 98 Record), Vol. 1, pp. 86-93, 1998.

69. Pandey, A., Dasgupta, N., and Mukerjee, A. K., "High-Performance Algorithms for Drift Avoidance and Fast Tracking in Solar MPPT System," IEEE Transactions on Energy Conversion, Vol. 23, No. 2, pp. 681-689, 2008.

70. Hua, C. and Shen, C., "Comparative Study of Peak Power Tracking Techniques for Solar Storage System," Proc. of Thirteenth Annual Applied Power Electronics Conference and Exposition(APEC '98), Vol. 2, pp. 679-685, 1998.

71. Hohm, D. P. and Ropp, M. E., "Comparative Study of Maximum Power Point Tracking Algorithms using an Experimental, Programmable, Maximum Power Point Tracking Test Bed," Proc. of the Twenty-Eighth IEEE Photovoltaic Specialists Conference, pp. 1699-1702, 2000.

72. Subudhi, B. and Pradhan, R., "A Comparative Study on Maximum Power Point Tracking Techniques for Photovoltaic Power Systems," IEEE Transactions on Sustainable Energy, Vol. 4, No. 1, pp. 89-98, 2013.

73. Kim, S. -K., Kim, E. -S., and Ahn, J. -B., "Modeling and Control of a Grid-connected Wind/PV Hybrid Generation System," Proc. of 2005/2006 IEEE PES Transmission and Distribution Conference and Exhibition, pp. 1202-1207, 2006.

74. Giraud, F. and Salameh, Z. M., "Steady-State Performance of a Grid-Connected Rooftop Hybrid Wind-Photovoltaic Power System with Battery Storage," IEEE Power Engineering Review, Vol. 21, No. 2, pp. 54-54, 2001.

75. Cristaldi, L., Faifer, M., Rossi, M., and Toscani, S., "An Improved Model-Based Maximum Power Point Tracker for Photovoltaic Panels," IEEE Transactions on Instrumentation and Measurement, Vol. 63, No. 1, pp. 63-71, 2014.

76. Masoum, M. A. S., Dehbonei, H., and Fuchs, E. F., "Theoretical and Experimental Analyses of Photovoltaic Systems with Voltageand Current-Based Maximum Power-Point Tracking," IEEE Transactions on Energy Conversion, Vol. 17, No. 4, pp. 514-522, 2002.

77. Spiazzi, G., Buso, S., and Mattavelli, P., "Analysis of MPPT Algorithms for Photovoltaic Panels Based on Ripple Correlation Techniques in Presence of Parasitic Components," Proc. of Power Electronics Conference (COBEP '09), pp. 88-95, 2009.

78. Ibrahim, H. E. S. A., Houssiny, F. F., El-Din, H. M. Z., and ElShibini, M. A., "Microcomputer Controlled Buck Regulator for 
Maximum Power Point Tracker for DC Pumping System Operates from Photovoltaic System," Proc. of IEEE International Fuzzy Systems Conference, Vol. 1, pp. 406-411, 1999.

79. Kurokami, S. and Takehara, N., "Power control apparatus and method and power generating system using them," US Patents, No. EP0628901 A2, 1994

80. Fangrui, L., Kang, Y., Zhang, Y., and Duan, S., "Comparison of P\&O and Hill Climbing MPPT Methods for Grid-Connected PV Converter," Proc. of 3rd IEEE Conference on Industrial Electronics and Applications(ICIEA), pp. 804-807, 2008.

81. Zbeeb, A., Devabhaktuni, V., and Sebak, A., "Improved Photovoltaic MPPT Algorithm Adapted for Unstable Atmospheric Conditions and Partial Shading," Proc. of International Conference on Clean Electrical Power, pp. 320-323, 2009.

82. Onat, N., "Recent Developments in Maximum Power Point Tracking Technologies for Photovoltaic Systems," International Journal of Photoenergy, Vol. 2010, pp. 1-11, 2010.

83. Salas, V., Olías, E., Barrado, A., and Lázaro, A., "Review of the Maximum Power Point Tracking Algorithms for Stand-Alone Photovoltaic Systems," Solar Energy Materials and Solar Cells, Vol. 90, No. 11, pp. 1555-1578, 2006.

84. Esram, T. and Chapman, P. L., "Comparison of Photovoltaic Array Maximum Power Point Tracking Techniques," IEEE Transactions on Energy Conversion, Vol. 22, No. 2, pp. 439-449, 2007.

85. Karabacak, K. and Cetin, N., "Artificial Neural Networks for Controlling Wind-PV Power Systems: A review," Renewable and Sustainable Energy Reviews, Vol. 29, pp. 804-827, 2014.

86. Altas, I. H. and Sharaf, A. M., "A Novel Maximum Power Fuzzy Logic Controller for Photovoltaic Solar Energy Systems," Renewable Energy, Vol. 33, No. 3, pp. 388-399, 2008.

87. Duryea, S., Islam, S., and Lawrance, W., "A Battery Management System for Stand-alone Photovoltaic Energy Systems," IEEE Industry Applications Magazine, Vol. 7, No. 3, pp. 67-72, 2001.

88. Jongerden, M. R. and Haverkort, B. R., "Which Battery Model to use?” Proc. 25th U.K. Perform. Eng. Workshop, pp. 76-88, 2008.

89. Dürr, M., Cruden, A., Gair, S., and McDonald, J. R., "Dynamic Model of a Lead Acid Battery for Use in a Domestic Fuel Cell System,” Journal of Power Sources, Vol. 161, No. 2, pp. 1400-1411, 2006.

90. Diaf, S., Belhamelb, M., Haddadic, M., and Louchea, A., "Technical and Economic Assessment of Hybrid Photovoltaic/Wind System with Battery Storage in Corsica Island," Energy Policy, Vol. 36, No. 2, pp. 743-754, 2008.

91. Bin, A., Hongxing, A., Hui, S., and Xianbo, L., "Computer Aided Design for Pv/Wind Hybrid System," Proc. of the 3rd World Conference on Photovoltaic Energy Conversion, Vol. 3, pp. 2411$2414,2003$.

92. Borowy, B. S. and Salameh, Z. M., "Methodology for Optimally
Sizing the Combination of a Battery Bank and PV Array in a Wind/ PV Hybrid System," IEEE Transactions on Energy Conversion, Vol. 11, No. 2, pp. 367-375, 1996. 